Zbornik Instituta za kriminološka

i sociološka istraživanja

2021 / Vol. XL / 1 / 103-132

Pregledni naučni rad

Primljeno: 8. februara 2021. godine

Prihvaćeno: 11. maja 2021. godine

DOI: $10.47152 /$ ziksi2021016

UDK: 47.172-053.31(497.11)

\title{
POTREBA I MOGUĆNOSTI PRAVNOG SAGLEDAVANJA I TRETMANA NESTANKA BEBA
}

\author{
Vladan Joldžić*
}

\begin{abstract}
Predmet rada, očigledan iz samog naslova, proizašao je iz našeg interesovanja postoji li adekvatna društveno-pravna reakcija na nestanak beba iz porodilišta, a naročito na domaćem terenu. Reč je o pojavi za koju se turdi da je decenijama prisutna ne samo u Srbiji već praktično u svim državama. Pri tom je, u Srbi̋i, duži niz godina, od roditelja koji turde da im je beba ukradena iz porodilišta, ali $i$ odlukom Evropskog suda za ljudska prava u slučaju Zorica Jovanović protiv Srbije, traženo da se donese zakon koji bi to tretirao na odgovarajući način. Otuda ne čudi da se u Srbiji na njemu radilo još od 2014. godine. Kada je donet odmah je izazvao kontraverze, pa tako i naše sumnje i želju da ga analiziramo, te da na taj način ukažemo i na moguće puteve, načine $i$ elemente neophodne za korekciju njegovih manjkavosti (ukoliko ih uočimo), što nam i jeste cilj ovoga rada.
\end{abstract}

KLJUČNE REČI: međunarodno parvo / Ustav / zakoni / institucije / zaštita prava

\footnotetext{
${ }^{*}$ Prof. dr Vladan Joldžić, naučni savetnik, Institut za kriminološka i sociološka istraživanja, Beograd. E-mail: joldzicvladan2@gmail.com,vladanj@eunet.rs
} 


\author{
Zbornik IKSI, 1/2O21 - V. Joldžić \\ „Potreba i mogućnosti pravnog sagledavanja i tretmana nestanka beba”, (str. 103-132)
}

\title{
1. PREDMET, CILJ I METODI RADA
}

„Potreba i mogućnosti pravnog sagledavanja i tretmana nestanka beba“, kako sam naslov definiše, osnovni je predmet našeg rada, koji Vam ovim tekstom plasiramo. Radi se o pojavi za koju se tvrdi, kako od strane brojnih roditelja, tako i stručne te naučne javnosti, da je decenijama prisutna praktično u svim državama, da ima više oblika ispoljavanja, među kojima i krađe beba iz porodilišta. Takođe i da zahteva adekvatne pravne reakcije, pa i drugačije nego li su unutar nekih država regulisane. Takve tvrdnje su iznete i unutar Republike Srbije. Ovo nas je zainteresovalo. Postavili smo sebi za osnovni cilj da sagledamo pravni pristup dotičnom problemu unutar naše države, kao i da li treba nešto da se učini na planu zaštite prava roditelja i beba, te ako treba, šta bi to bilo logično da se uradi na legislativnom, otuda i praktičkom planu?

Da bi adekvatno obradili predmet svog rada, a u skladu sa postavljenim ciljem, bio nam je neophodan odgovarajući metodološki aparat. U isti ulaze pojedini metodi pravnih i društvenih nauka. Objasnimo.

Iako su pravni odnosi u svojoj ukupnosti određeni pravom kao dogmatskom tvorevinom, to ni u kom slučaju ne znači da pravo ne podleže razvojnoj (dijalektičkoj) logici, paralelno pojavi i razvoju pojedinih problema, pa tako i pod uticajem obaveza preuzetih ratifikovanjem jednog broja međunarodnih konvencija. Samim tim se pravu (i na domaćem terenu) mora priznati razvojna priroda. I to kako normativno-razvojna, tako i normativno-praktička, na polju primene važećih normi usmerenih na zaštitu formalno-pravno uspostavljenih prava, vrednosti i odnosa. Ovo nas orijentiše ka razmatranju par vrsta normativnog metoda, pre svih normativno-pravnog, formalno-normativnog i materijalno-normativnog. Svaki od ovih metoda, upravo zbog svoje specifičnosti, primeren je predmetu našeg rada.

Oslanjajući se na normativno-pravni metod mi to činimo polazeći od svesti o tome da pravno sagledavanje problematike obuhvaćene predmetom istraživanja, kako na unutarnje pravnom tako i na međunarodno pravnom područiju, nije strukturno celovito, niti jasno definisane hijerahije normi. Otuda se normativno-pravni metod pokazuje kao nužan, upravo da bi smo u ovom mnoštvu normi sagledali njihovu formalnu stranu. Dakle njihovu pravnu snagu i međusobni hijerarhijski odnos. Bez njega bi to bilo nemoguće, a time ni cilj koji smo sebi postavili ne bi bio ostvariv.

Formalno-normativni metod potreban nam je radi utvrđivanja pravne snage akata kojima se stvaraju norme što uređuju elemente posmatranog odnosa. Bolje rečeno, jesu li to:

1.) međunarodni, ili

2.) originerni tekstovi pozitivnog zakonodavstva države (zakonskim, ili podzakonskim tekstovima). 


\author{
Zbornik IKSI, 1/2O21 - V. Joldžić \\ „Potreba i mogućnosti pravnog sagledavanja i tretmana nestanka beba”, (str. 103-132)
}

Dobivši odgovor na ova pitanja stičemo osnovicu za primenu materijalnonormativnog metoda. Osnovni zadatak materijalno-normativnog metoda jeste sređivanje (stvaranje) slike pravnih normi obzirom na njihovu sadržinu. A ona nam je neophodna za formiranje i naših razmišljanja o pojavi kojoj smo posvetili pažnju, kao i tome šta bi u vezi iste valjalo da se učini na planu dogradnje važećeg zakonodavstva Republike Srbije.

Prihvativši operacionu definiciju predmeta „potreba i mogućnosti pravnog sagledavanja i tretmana nestanka beba“, a koji valja posmatrati polazeći od sa ovom pojavom povezivih unutarnje pravnih kao i usvojenih normi međunarodnog prava, jasno je da ove nestanke moramo da posmatramo pojedinačno, ali i kao skup. To nas vodi ka korišćenju logički formiranih metoda korišćenih u sklopu društvenih nauka.

Kako dostupna materija može da omogući dosta širok uvid u sam predmet, razumljivo je da je pogodna za analitičku obradu. Ovakav metodološki pristup znači neizbežno korišćenje induktivnog metoda. Za nas je induktivni metod od velikog značaja. „Saznajna uloga... nije samo deskriptivna nego je i eksplikativna” (Šešić, 1974: 109). Deskripcija, naročito kvantitativni opis, ne može se oštro i strogo odvojiti od eksplikacije, to jest objašnjenja suštine onoga čime se i u ovom radu bavimo.

Iz razloga valjanog saznanja predmeta „potrebe i mogućnosti pravnog sagledavanja i tretmana nestanka beba“ poželjno je ući i u sagledavanje adekvatnog primera posmatrane pojave (tzv: case Study). „Ova metoda je analitička i induktivna, jer polazi od konkretnih slučajeva. Samo izravno poznavanje procesa dopušta da se o njemu govori” (Gilli, 1974: 103). Tek ovakav metodološki pristup u izučavanju predmeta kakav je naš može dati validan pristup, otuda i rezultate. U svom radu ova pravila i mi očigledno usvajamo obzirom da smo se u svom radu upustili ne samo u analizu konkretnih tekstova međunarodnog prava od značaja za posmatrani predmet istraživanja, kao i elemenata domaćeg zakonodavstva od značaja za tretman istog, već smo pre toga ukazali na analitičke elemente stranih autora a koji nam ukazuju na slučajeve samih pojava nestanka beba iz porodilišta, kao i na onaj koji se odnosi na problem na koji je ukazao Evropski sud za ljudska prava u Predmetu Zorica Jovanović protiv Srbije (European Court for Human Rights, Second Section, Case of Zorica Jovanović v. Serbia, 2013).

\title{
2. ULAZ U MATERIJU
}

U radu koji Vam prezetiramo pažnju nam je privuklo ukazivanje, kako sredstava javnog informisanja tako i stručne te naučne javnosti, na probleme nestanaka beba, kao i potrebe adekvatnog pravnog reagovanja na ista. Reagovanja koja bi valjalo da se baziraju na brojnim važećim elementima prava, uključujući i kaznenog prava.

Krađa novorođenčadi je dugi niz godina tema koju obrađuju stručnjaci različitih profila. Pa je tako dvoje američkih autora, u radu "Sprečavanje otmice novorođenčadi” ukazalo da se radi o rastućoj pojavi (Beachy, Deacon, 1992: 13), i to: deliktu očajnika - ženske osobe koja želi da ima bebu, ili pak o unapred smišljenom aktu često počinjenom i uz saradnju neke druge osobe ili osoba, najčešće medicinskog osoblja iz porodilišta (Beachy, Deacon, 1992: 14). O ovome takođe 
govori Viktorija Karol, ukazujući da medicinsko osoblje može da izvrši dotični kriminalni akt, ili, ako postupa ispravno, da ga spreči (Carroll, 1999: 26).

Ulazeći u razmišljanja o krađi beba iz porodilišta na ovom mestu ukazujemo da su $\mathrm{SAD}$, kao država sa velikim brojem stanovnika, na ovu pojavu tokom godina sve više obraćale pažnju, i to ne samo javnosti već i struka. Otuda je, primera radi, prvo 1995. godine, a potom i 2003. godine, izvršeno istraživanje "Analiza krađe novorođenčadi" (Burges, Lanning, 2003), i to u saradnji: National Center for Missing \& Exploited Children (NCMEC), iz Njujorka, The National Center for the Analysis of Violent Crime (NCAVC), ustanove u okviru takozvane FBI's Critical Incident Response Group, i Office of Juvenile Justice and Delinquency Prevention, kancelarije Minstarstva pravde USA (U.S. Department of Justice). Već u samom Uvodu ovog teksta (str. VIII) je rečeno da se radi o rastućoj pojavi o kojoj se ne izveštava dovoljno, a da se akt krađe novorođenčeta često izvršava iz razloga kriminalne zarade. Šta više ovo istraživanje je pokazalo da se krađa novorođenčeta najčešće odvija kroz četiri faze:

- praćenje nečije trudnoće (pre odlaska u porodilište i potom, ili pak samo unutar istog),

- planiranje otmice,

- izvršavanje otmice, i

- postupanja posle otmice (Burges, Lanning, 2003: 39).

Kako je istraživanje pokazalo cilj ovog delovanja je ne samo ukrasti bebu već se "izvući od odgovornosti za izvršeni zločin. Ova faza odnosi se na to koliko dobro je osoba planirala da pobegne sa scene odvođenjem bebe, ali i da ponovo uđe u svoj društveni krug, a da niko ne osporava legitimitet odnosa sa detetom (Burges, Lanning, 2003: 42). Zarad toga osoba ili osobe koje žele bebu često ne izvršavaju dotični akt same već sarađuju sa najmanje jednom a često i više osoba, kako to kaže Džon Rebin u svojoj knjizi "Za zdravstvene radnike: Smernice za sprečavanje i odgovor na otmice dojenčadi” (Rabun, 1996). Ovaj autor jasno kaže da otmičar novorođenčeta može biti nepoznata osoba, osoba koja se predstavlja kao medicinska sestra ili pak zaposlen u bolnici” (Rabun, 1996: 4). Ovo isto kaže i Tomas Kolins u svom članku "Kod pink" sačinjenom na bazi istraživanja 230 slučajeva (Case Study) u vremenu 1983-2004.godine (Collins, 2006). Ali to uistinu može biti i neko ko jeste stvarno zaposlen u porodilištu.

Tekstovi koje smo citirali ukazuju nam da se veoma često, upravo u porodilištima, pojavljuje problem da porodilja ne dobija novorođenče, već joj se saopštava da se dete rodilo mrtvo, ili jeste umrlo nakon porođaja, ali da se dotično mrtvorođenče ne predaje roditelju. Pri tom se, mada ne uvek, dešava i da ovakvo postupanje ne prate bilo kakvi za to propisani dokumenti, ili ih prate dokumenti koje bi svaki iole upućeniji pravnik smatrao pravno nevaljanim. Obzirom na to, kao i činjenicu da je ova pojava, izvedena na razne načine, uistinu decenijama prisutna, to je razumljivo da su o njoj pisani ne samo radovi struka, članci, studije i knjige, već i naučni radovi, među kojima, primera radi, i magistarske teze studenata prava. Pa tako Gema Patricia Barenčea Lopez u svom magistraskom radu "Rod u prelaznim kontekstima 
pravde: Reproduktivna prava u španskom slučaju ukradenih beba" (Barrenechea López, 2017), jasno kaže da se radi o pojavi ispoljenoj u javnim i privatnim porodilištima Španije, pri čemu se krše različita ljudska prava, ne samo krađe beba (doslovce "prisilnog nestanka") već i formiranja za to neophodne prateće lažne dokumentacije, a da se zanemaruje i rodna ravnopravnost (Barrenechea López, 2017: 34). Pri tome se ovaj kriminalni akt, kako autorka naglašava, ispoljava kao nasilje nad ženama ali i kao zločin protiv čovečnosti (Barrenechea López, 2017: 4042). Lopez dalje naglašava da je zarad formiranja identiteta bebe kao novorođenčeta žene koja ga uistinu nije rodila, osim delovanja osobe koja izvršava krađu novorođenčeta, neophodna i saradnja sa ljudima koji u tom protivzakonitom delovanju mogu da pomognu. Pa tako pomognu i u protivzakonitom formiranju dokumenata do kojih se inače može da dođe samo saradnjom sa nekim od činovnika lokalne vlasti zaduženim inače za zakonito izdavanje dokumenata $\mathrm{u}$ vezi novorođenčeta (Barrenechea López, 2017: 34.).

Ovoj pojavi je posvećena pažnja i u okviru sveukupne teme magistarskog rada Jelene Jovanović pod naslovom „Nadzor Komiteta ministara Saveta Evrope nad izvršavanjem presuda Evropskog suda za ljudska prava" (Jovanović, 2016). U ovom radu, polazeći od "Konvencije za zaštitu ljudskih prava i osnovnih sloboda" (Convention for the Protection of Human Rights and Fundamental Freedoms, 1950), jasno se kaže da su države članice Saveta Evrope u obavezi da primene presudu Evropskog suda za ljudska prava i sprovedu mere koje konkretna presuda nalaže državi članici (Jovanović, 2016: 37). Dotične mere mogu biti: 1. pravična satisfakcija (isplata), 2. neko konkretno činjenje, ali i 3. nalaganje usvajanja neke opšte mere (Jovanović, 2016: 33), naročito kada se radom Suda utvrdi da je u konkretnom slučaju došlo do povrede nekog ili nekih prava i zbog kakvog sistemskog nedostatka. "Svrha opštih mera je da se spreče nove ili slične povrede u budućnosti" (Jovanović, 2016: 42).

Citirani magistarski radovi, kao i svi prethodno navedeni tekstovi, jasno ukazuju na neophodnost tretmana krađe beba na bazi seta normi lociranih u važećim tekstovima međunarodnog prava ali i nacionalnih zakonodavstava. To zahteva legislativni razvoj na više pravnih nivoa: međunarodnog prava, ustava država, zakona koji su od značaja za pravilno ostvarivanje prava rađanja i ostvarivanje roditeljstva, ali i sankcionisanje njima suprotnog a pokušanog ili izvršenog kažnjivog delanja. Otuda je to osnov naših razmišljanja plasiranih u sledećoj fazi izlaganja. 


\title{
3. ELEMENTI PRAVA OD ZNAČAJA ZA PRISTUP SAGLEDAVANJU PROBLEMATIKE NESTALIH BEBA
}

\author{
3.1. Elementi međunarodnog prava od značaja za sagledavanje \\ problematike nestalih beba
}

U ovom momentu kao jedan od najznačajnijih, a mi smatramo (polazeći od normativnih metoda) i najznačajniji dokument međunarodnog javnog prava od značaja i za našu temu jeste Univerzalna deklaracija o ljudskim pravima (The Universal Declaration of Human Rights, 1948), koja, mada oficijelno nazvana deklaracijom, jeste formirana logikom izgradnje legislativnog akta, a tokom godina kao takav akt je i opšte prihvaćena od gotovo svih suverenih država ${ }^{1}$. Koji su to njeni elementi od značaja za problematiki nestanaka beba te potreba i mogućnosti pravnog sagledavanja i tretmana iste? Krenimo redom.

U članu 2. stoji da „svakom pripadaju prava proglašena ovom Deklaracijom“. Pri tome član 3. jasno kaže da „svako ima pravo na život, slobodu i bezbednost ličnosti“. Otuda je logično što čl. 5 . propisuje da se „niko... ne sme podvrgnuti... nečovečnom ili ponižavajućem postupanju“. Samim tim, po osnovu člana 10., ,,svako ima potpuno jednako pravo na pravično suđenje pred nezavisnim i nepristrasnim sudom“. Za našu temu je od značaja i to što Deklaracija, svojim članom 12., jasno propisuje da se „niko... ne sme izložiti proizvoljnom mešanju u privatni život... (te) porodicu“.

Podsećamo da ova, opšte određena, prava dotičnom Deklaracijom, principijelno, a vremenski ili bilo na koji drugi način, nisu ograničena. Ali zato jesu sveobuhvatnije obrađivana i razrađivana potonjim aktima globalno i kontinentalno usmerenih legislativnih akata međunarodnog prava, uz naglašavanje poštovanja same Deklaracije.

Među legislativnim elementima međunarodnog prava od nesumnjivog značaja za sagledavanje problematike nestalih beba je i Međunarodni pakt o građanskim i političkim pravima (International Covenant on Civil and Political Rights, 1966). Već u Preambuli ovog Pakta jasno je rečeno da je „priznavanje dostojanstva... bitno za sve članove ljudske porodice i njihovih jednakih i neotuđivih prava“, te da predstavlja „prema Opštoj deklaraciji o pravima čoveka, ideal slobodnog ljudskog bića koje uživa građanske i političke slobode i koje je oslobođeno od straha i bede“, a da se ovo „može postići samo ako se stvore uslovi koji omogućavaju svakome da uživa svoja građanska... kao i socijalna i kulturna prava“. Iz tog razloga, po osnovu člana 2., stava 1., države članice su se obavezale „da poštuju i garantuju svim licima koja se nalaze na njihovoj teritoriji i koja potpadaju pod njihovu nadležnost, prava priznata ovim Paktom“ i to bez obzira na "nacionalno ili socijalno poreklo, imovno

\footnotetext{
${ }^{1}$ Interesantno je napomenuti da te, 1948.godine, među 8 država koje je nisu glasale za njeno usvajanje (bile su uzdržane) spada i tadašnja Jugoslavija (FNRJ), čiji je pravni naslednik Republika Srbija. Ali ne sme da se previdi da isti akt sada, obzirom na opštu prihvaćenost, prihvata i sama Srbija.
} 
stanje, rođenje ili svaku drugu okolnost“. Otuda (po osnovu čl. 2., st. 2.) i da „u skladu sa svojim ustavnim postupkom i odredbama ovog Pakta, preduzmu korake koji bi omogućili usvajanje takvih zakonskih ili drugih mera kojima mogu da ostvare prava priznata ovim paktom“. Države Strane ovog akta, što znači i Srbija, po osnovu člana 3., stava 1., u obavezi su da:

„(a) garantuju da se svako lice čija su prava i slobode priznati ovim paktom povređeni, može koristiti pravom žalbe, čak i ako su ih povredila lica u vršenju svojih zvaničnih dužnosti;

(b) garantuju da će nadležne sudske, upravne ili zakonodavne vlasti ili svaka druga nadležna vlast prema propisima države, rešavati o pravima lica koje podnosi žalbu, i da prošire mogućnosti podnošenja žalbe pred sudom; i

(c) garantuju da će nadležne vlasti povoljno rešiti svaku žalbu koja bude smatrana opravdanom“.

„Međunarodni pakt o građanskim i političkim pravima“, posebno članom 5., stavom 2., propisuje da se „ne priznaje... nikakvo ograničenje ili odstupanje od osnovnih prava čoveka koja su priznata ili važe u svakoj državi članici ovog Pakta na osnovu primene zakona, konvencije, propisa ili običaja“. U cilju zaštite ljudskih prava takođe je propisano:

- članom 7., da „niko ne može biti podvrgnut... nehumanim... postupcima“;

- članom 17.,

- st. 1. da „niko ne može biti predmet samovoljnih ili nezakonitih mešanja u njegov privatni život, u njegovu porodicu“; a

- st. 2. da „svako lice ima pravo na zaštitu zakona protiv ovakvih mešanja ili povreda“,

pri čemu je jasno rečeno (članom 23.) da je „porodica... prirodni i osnovni sastavni deo društva i ima pravo na zaštitu društva i države“.

Kako nas u vom radu posebno interesuje zaštita dece, pre svega novorođenčadi, od značaja nam je i: član 24. koji decidno propisuje da „svako dete, bez diskriminacije zasnovane na rasi, boji, polu, jeziku, veri, nacionalnom ili socijalnom poreklu, imovnom stanju ili rođenju, ima pravo da mu njegova porodica, društvo i država ukazuju zaštitu koju zahteva njegov status maloletnika (st. 1.)“, a da „odmah posle rođenja, svako dete mora biti upisano u matičnu knjigu rođenih i nositi neko ime (st. 2.)“, ali i član 26. koji jasno kaže da su „sva... lica jednaka pred zakonom i imaju pravo bez ikakve diskriminacije na podjednaku zaštitu zakona“.

Kako se u ovom radu bavimo materijom koja se može definisati kao otmica dece jasno je da je za nas od značaja i Konvencija o građanskopravnim aspektima međunarodne otmice dece (Hague Convention on the Civil Aspects of International Child Abduction, 1980), koju smo ratifikovali (Zakon o ratifikaciji Konvencije o građanskopravnim aspektima međunarodne otmice dece, Sl. list SFRJ - Međunarodni ugovori, br. 7/1991). Konvencija, članom 3., stavom 1., 
jasno propisuje da se odvođenje dece proglašava nezakonitim. Takođe i da se ista primenjuje na dete koje je živelo u državi ugovornici pre bilo kakve povrede na staranje, a do navršenih 16 godina starosti (čl. 4.). Takođe je jasno rečeno, članom 8., da se „bilo koje lice, institucija ili drugo telo koje tvrdi da je odvođenjem ili zadržavanjem deteta povređeno pravo na staranje može... obratiti centralnom izvršnom organu države u kojoj se nalazi mesto stalnog boravka deteta ili centralnom izvršnom organu koje druge države ugovornice za pomoć u obezbeđivanju povratka deteta“.

Za adekvatan pravni tretman nestanka beba od izuzetnog značaja je i Konvencija saveta Evrope o borbi protiv trgovine ljudima, koju smo ratifikovali (Zakon o potvrđivanju Konvencije Saveta Evrope o borbi protiv trgovine ljudima, Sl. glasnik RS - Međunarodni ugovori, br. 19/2009). Ova Konvencija se primenjuje na sve oblike trgovine ljudima, na nacionalnom kao i nadnacionalnom planu, bez obzira da li je ili nije povezana sa organizovanim kriminalom (čl. 2.), što znači i trgovinom bebama ukradenim iz porodilišta. Konvencija (članom 5., st. 1.) obavezuje sve države Strane na preduzimanje mera putem kojih bi uspostavile i učvrstile koordinaciju različitih nacionalnih tela nadležnih za suzbijanje i sprečavanje trgovine ljudima, a posebno trgovine decom (čl. 5., st. 5.). Iz istog razloga Strane ugovornice ove Konvencije su obavezane (članom 6.) na usvajanje i neophodnih zakonskih mera. Takođe se od država članica zahteva formiranje kadrova sposobnih za sprečavanje trgovine ljudima i identifikaciju zrtava te pružanja pomoći istim (čl. 10.). A da bi se trgovina ljudima adekvatno tretirala Konvencija zahteva (Poglavljem IV, članom 19.) kriminalizaciju trgovine ljudima, zatim kriminalizaciju dela koja se odnose na putne ili lične isprave (čl. 20.), ali (po osnovu čl. 21.) i: 1. pokušaja izvršenja, te 2. pružanja pomoći u izvršenju navedenih delikata, kao i 3. podsticanja na isto, odnosno ista. Obzirom da se često dobar deo radnji u postupku krađe bebe može da izvrši radom unutar pravnog lica to Konvencija (članom 22., stavom 1.) zahteva da svaka država članica donese "zakonodavne ili druge mere koje su potrebne da se obezbedi da pravno lice može biti odgovorno za krivično delo predviđeno ovom Konvencijom, ako ga je izvršilo fizičko lice u korist tog pravnog lica, bilo da je postupalo samostalno ili kao deo nekog organa tog pravnog lica, ako se nalazi na rukovodećem položaju u okviru tog pravnog lica, na osnovu:

a.) ovlašćenja da zastupa to pravno lice;

b.) ovlašćenja da donosi odluke u ime tog pravnog lica;

c.) ovlašćenja da vrši nadzor u okviru tog pravnog lica”.

Šta više, stavom 2. posmatranog člana 22., Konvencija propisuje da će „svaka članica... preduzeti potrebne mere kako bi obezbedila da pravno lice može biti odgovorno kada je odsustvo nadzora ili kontrole od strane fizičkog lica iz stava 1. čl. 22. omogućilo izvršenje krivičnog dela u skladu s ovom Konvencijom, od strane fizičkog lica koje postupa po ovlašćenju tog pravnog lica a u korist tog pravnog lica“. Pri tom Konvencija saveta Evrope o borbi protiv trgovine ljudima svojim članom 24., pod (a), predviđa da je otežavajuća okolnost ukoliko se delikt izvrši prema detetu, ili pak u okviru kriminalne organizacije [čl. 24., pod (d)]. 
Za našu temu takođe su od značaja i elementi globalnog legislativnog dokumenta, „Međunarodnog pakta o ekonomskim, socijalnim i kulturnim pravima” (International Covenant on Economic, Social and Cultural Rights, 1966), koju smo ratifikovali (Zakon o ratifikaciji Međunarodnog pakta o ekonomskim, socijalnim i kulturnim pravima, Sl. list SFRJ, br. 7/1971). Dotični Pakt, svojom preambulom, jasno kaže da se ova prava smatraju za neotuđiva za svakog člana ljudske porodice, te da se iz tog razlog, a polazeći i od „Povelje UN” (Charter of the United Nations, San Francisco, 1945), državama nameće obaveza da unapređuju stvarno njihovo poštovanje. A to znači i poštovanje svih socijalnih prava! I to bez ikakve diskriminacije (čl. 2., st. 1.). Pri tom i da države članice, po osnovu člana 10., st. 1., pruže „zaštitu i pomoć porodici“, a ista zaštita da treba da bude posebno pružena „majkama za razumno vreme pre i posle rođenja dece (čl. 10., st. 2.)“.

U razmatranjima elemenata međunarodnog javnog prava od značaja za temu ovog rada značajno mesto zauzima i „Evropska konvencija za zaštitu ljudskih prava i osnovnih sloboda" (Convention for the Protection of Human Rights and Fundamental Freedoms, 1950), upravo ona njena varijanta koju smo usvojili ratifikacijom (Zakon o ratifikaciji Evropske Konvencije za zaštitu ljudskih prava i osnovnih sloboda, Sl. List SRJ, 9/2003, Sl. glasnik RS, 12/2010 i 10/2015). Ova Konvencija svojim „Čanom 5. Pravo na slobodu i bezbednost“ jasno propisuje da svako ima pravo na bezbednost. A to znači i bilo koje novorođenče. Takođe, po osnovu stava 1. „Člana 6. Pravo na pravično suđenje“, svako ima pravo da se tokom odlučivanja o njegovim građanskim, što znači i roditeljskim pravima te pravu bebe na identitet i biološke roditelje, odlučuje kroz „pravičnu i javnu raspravu u razumnom roku pred nezavisnim i nepristrasnim sudom“. Pri tom „svako ima pravo na poštovanje svog privatnog i porodičnog života (Čl. 8.)“. Samim tim „svako kome su povređena prava i slobode predviđeni u ovoj Konvenciji ima pravo na delotvoran pravni lek pred nacionalnim vlastima, bez obzira jesu li povredu izvršila lica koja su postupala u službenom svojstvu (Član 13. Pravo na delotvorni pravni lek)“.

Za nas je od posebnog značaja i Konvencija Ujedinjenih nacija o pravima deteta (Convention on the Rights of the Child, 1989). Ova Konvencija obavezuje države Strane na zaštitu svakog deteta (do navršene 18. godine života - čl. 1.) putem rada njenih institucija (čl. 3.), a kroz zakonodavne i administrativne mere (čl. 4.), pri čemu se (po osnovu čl. 7., st. 1.) „dete... prijavljuje odmah nakon rođenja i od rođenja ima pravo na ime, pravo na staranje, državljanstvo i, ako je to mogucee, pravo da zna ko su mu roditelji i pravo na njihovo staranje“ a države (po osnovu čl. 8.) „obezbeđuju ostvarivanje ovih prava u skladu s nacionalnim zakonom i svojim obavezama u skladu sa odgovarajućim međunarodnim instrumentima iz ove oblasti“. U „slučajevima kada je dete nelegalno lišeno nekih, ili svih, elemenata svog identiteta, države članice pružaju odgovarajuću pomoć i zaštitu kako bi mu što brže bio vraćen identitet (čl. 8., st. 2.)“. U tom cilju (a po osnovu čl. 11., st. 1.) „države članice preduzimaju mere za borbu protiv nelegalnog transfera i nevraćanja dece iz inostranstva“.

Posmatranom setu legislativnih tekstova međunarodnog prava, za koje smatramo da su od značaja za našu temu, pridružujemo i knjigu "Pregovaračka poglavlja: 35 koraka ka Evropskoj uniji” (Negotiation Chapters: 35 Steps towards the European 
Union, 2014). Unutar nje, pod "Brojem 23 - Pravosuđe i osnovna uprava" jasno je rečeno da država koja želi da se pridruži Uniji mora da poštuje standarde na kojima se temelji Evropska Unija, te da pravosuđe i osnovna uprava valjano rade. Pri tome i da efikasno štite osnovna ljudska prava. A da bi to uistinu bilo ostvarivo neophodno je da se ispoštuju i zahtevi "Poglavlja 24 - Pitanja pravde, slobode i bezbednosti", te da se prate pravni zahtevi EU povezani sa ovim vrednostima i pravima. Otuda i zahtevi usmereni na zaštitu prava ljudi uošte, time i novorođenčadi. A za to jeste neophodan adekvatan tekst Zakona o utvrđivanju činjenica o statusu novorođene dece za koju se sumnja da su nestala iz porodilišta u Republici Srbiji (Sl. glasnik RS, br. 18/2020).

\subsection{Ustavno pravni pristup sagledavanju problematike nestalih beba}

Ulazeći u problematiku nestanka beba, kao i potreba i mogućnosti njenog pravnog sagledavanja i tretmana, na prvom mestu smo ukazali na one najopštije, istovremeno i najznačajnije, elemente međunarodnog prava od uticaja na ove procese. Da bi dotični elementi uistinu bili primenljivi potrebno je da ih suverene države inkorporiraju u svoj sistem zakona. Ovo zahteva, na prvom mestu, adekvatno ustavno-pravno regulisanje koje to omogućava ali i principijelno reguliše, te, na drugom mestu, postojanje za to neophodnih zakona putem kojih se akti međunarodnog prava uključuju u legislaturu države. Takav zakon imala je i država predecesor - Jugoslavija (Zakon o zaključivanju i izvršavanju međunarodnih ugovora, Sl. listu SFRJ, br. 55/78, 2/89 i 47/1989) a poseduje ga i Republika Srbija (Zakon o zaključivanju i izvršavanju međunarodnih ugovora, Sl. glasnik $R S$, broj 32/2013). Pri tom za ovo nisu dovoljne samo one norme koje izričito govore o uključivanju dotičnih međunarodno-pravnih elemenata u domaći sistem zakona. Ovo posebno važi za zaštitu ljudskih prava, kako na političkom tako i čisto pravnom nivou. Objasnimo to upravo elementima Ustava (Službeni glasnik Republike Srbije, 2006).

Na samom početku Ustava, Članom 3. - Vladavina prava, jasno je propisano da je „vladavina prava... osnovna pretpostavka Ustava i (da) počiva na neotuđivim ljudskim pravima (st. 1.)“ ali i da se ostvaruje, između ostalog, ,ustavnim jemstvima ljudskih i manjinskih prava (kao i) podelom vlasti, nezavisnom sudskom vlašću i povinovanjem vlasti Ustavu i zakonu (st. 2.).“

Ustav jasno definiše normativno-hijerarhijske odnose, na prvom mestu stavljajući svoje norme kao norme osnovnog zakona države, ali locirajući odmah ispod sebe „opšte priznate principe i pravila međunarodnog prava (Član 16.- Međunarodni odnosi, stav 1.). Pri tom jasno propisuje da su „opšteprihvaćena pravila međunarodnog prava i potvrđeni međunarodni ugovori sastavni... deo pravnog poretka Republike Srbije i (da se) neposredno... primenjuju (čl. 16., st. 2.)“. Ova pravila su potvrđena i razrađena Članom 194. - Hijerarhija domaćih i međunarodnih opštih prravnih akata, koji (svojim stavom 3.) jasno propisuje da „svi zakoni i drugi opšti akti doneti u Republici Srbiji moraju biti saglasni sa Ustavom“, kao i (po osnovu stava 4. čl. 194.) da su „potvrđeni međunarodni ugovori i opšteprihvaćena pravila međunarodnog prava deo... pravnog poretka Republike 
Srbije“, ali i da, kako to propisuje stav 5. člana 194., „zakoni i drugi opšti akti doneti u Republici Srbiji ne smeju biti u suprotnosti sa potvrđenim međunarodnim ugovorima i opšte prihvaćenim pravilima međunarodnog prava“.

Ustav poseduje, u svom „Drugom delu - Ljudska i manjinska prava“, niz normi od značaja za našu analizu, samim tim i potonja ukazivanja na jedan broj manjkavosti ponajviše pristeklih iz Zakona o postupku utvrđivanja činjenica o statusu novorođene dece za koju se sumnja da su nestala u porodilištima u Republici Srbiji. Ustavni Član 18. - Neposredna primena zajemčenih prava, svojim stavom 1., jasno propisuje da se „ljudska i manjinska prava zajemčena Ustavom neposredno... primenjuju“, a da to posebno važi za „ljudska i manjinska prava zajemčena opšteprihvaćenim pravilima međunarodnog prava, potvrđenim međunarodnim ugovorima i zakonima (čl. 18., st. 2.)“, a da se „zakonom... može propisati način ostvarivanja ovih prava (ali) samo ako je to Ustavom izričito predviđeno ili ako je to neophodno za ostvarenje pojedinog prava zbog njegove prirode, pri čemu zakon ni u kom slučaju ne sme da utiče na suštinu zajemčenog prava (čl. 18., st. 2.)“. Pri tom se „odredbe o ljudskim i manjinskim pravima tumače... saglasno važećim međunarodnim standardima ljudskih i manjinskih prava, kao i praksi međunarodnih institucija koje nadziru njihovo sprovođenje (čl. 18., st. 3.)“. Za našu temu je izuzetno značajan i stav 2. „Člana 26. - Zabrana ropstva, položaja sličnog ropstvu i prinudnog rada“, jer se njime jasno propisuje da je „svaki oblik trgovine ljudima zabranjen“, a praksa je pokazala da je nestanak beba često posledica ovakve trgovine.

Treba imati u vidu i da Ustav jasno zabranjuje bilo kakvu diskriminaciju Članom 36. - Pravo na jednaku zaštitu sloboda i prava, jer propisuje (stavom 1.) da se ,jemči... jednaka zaštita prava pred sudovima i drugim državnim organima, imaocima javnih ovlašćenja i organima autonomne pokrajine i jedinica lokalne samouprave“, te da (po osnovu stava 2. čl. 36.) „Svako ima pravo na žalbu ili drugo pravno sredstvo protiv odluke kojom se odlučuje o njegovom pravu“. Zarad ostvarivanja prava na jednaku zaštitu i na jednakost u korišćenju pravnih sredstava formiran je i Član 56. Pravo na peticiju, kojim je jasno propisano da „svako ima pravo da, sam ili zajedno sa drugima, upućuje peticije i druge predloge državnim organima, organizacijama kojima su poverena javna ovlašcenja, organima autonomne pokrajine i organima jedinica lokalne samouprave i da od njih dobije odgovor kada ga traži (st. 1.)“. Jasno je da ovo važi i kada se postavljaju pitanja u vezi beba i sumnji u njihov nestanak, ali i zahteva zaštite njihovih i prava roditelja za koja se misli da su povređena nestankom novorođenčadi. Iz tog razloga je posebno značajan Član 64. - Prava deteta, koji jasno propisuje da „deca uživaju ljudska prava (st. 1.)“, pri čemu i „pravo na lično ime, upis u matičnu knjigu rođenih, pravo da sazna svoje poreklo i pravo da očuva svoj identitet (st. 2.)“, kao i da „su zaštićena od... svakog... iskorišćavanja ili zloupotrebljavanja (st. 3.)“. A da bi se ovo valjano ostvarivalo Ustav jasno, članom 64., stavom 5., propisuje, da se „prava deteta i njihova zaštita uređuju... zakonom“.

Kako se prava i dužnosti ljudi ne mogu da ostvare bez uspostavljanja nadležnosti, obaveza i odgovornosti državnog aparata, to je razumljivo da je za našu temu od značaja i Član 97. - Nadležnost Republike Srbije. Ovaj član, svojim stavom 1., tačkom 2., jasno propisuje da Republika obezbeđuje „ostvarivanje i zaštitu sloboda i 
prava građana; ustavnost i zakonitost; postupak pred sudovima i drugim državnim organima; odgovornost i sankcije za povredu sloboda i prava građana utvrđenih Ustavom i za povredu zakona, drugih propisa i opštih akata“, a stavom 4. da obezbeđuje i njihovu bezbednost. Takođe i brigu o deci (čl. 97., st. 1., t. 10.).

Za našu temu je od značaja i Član 138. - Zaštitnik građana, njegov stav 1., koji propisuje da je „Zaštitnik građana... nezavisan državni organ koji štiti prava građana i kontroliše rad organa državne uprave... kao i drugih organa i organizacija, preduzeća i ustanova kojima su poverena javna ovlašćenja“. A to znači da bi trebalo da može da kontroli podvrgne i rad onih organa i/ili organizacija za koje postoje osnovi sumnje da je unutar njihove strukture došlo do ponašanja koje je rezultovalo nestankom beba.

Razume se, da bi se prava ljudi ostvarivala i efikasno štitila neophodan je rad sudova. Ali rad koji se može da uredi samo u skladu sa Ustavom, njegovim Članom 142. Načela sudstva (st. 3.). Ovo važi i za rad Ustavnog suda, koji je regulisan Članom 168. - Ocena ustavnosti i zakonitosti. Njime je jasno propisano da „postupak za ocenu ustavnosti i zakonitosti mogu da pokrenu državni organi, organi teritorijalne autonomije ili lokalne samouprave, kao i najmanje 25 narodnih poslanika. (kao i da) postupak može pokrenuti i sam Ustavni sud (st. 1.)“. Takođe i da „svako pravno ili fizičko lice ima pravo na inicijativu za pokretanje postupka za ocenu ustavnosti i zakonitosti (st. 2.)“. Ustavni sud svojom odlukom može da utvrdi da „zakon ili drugi opšti akt... nije saglasan Ustavu ili (hijerarhijski višem) zakonu (st. 3.) te da zato isti „prestaje da važi danom objavljivanja odluke Ustavnog suda u službenom glasilu (st. 3.)“.

\section{UOČENI PROBLEMI ZAKONSKOG I PRAKTIČKOG PRISTUPA NESTANKU BEBA}

\section{1. Šta je i kako otvorilo procese sagledavanja problema nestalih beba u Republici Srbiji i zakonskog pristupa istom?}

Objašnjavajući, na prethodnim stranicama, predmet i cilj rada, kao i sam ulaz u materiju, sve to bazirajući na podacima iznetim unutar tekstova sa kojima smo se susreli, a odnose se na međunarodno-pravne odnose kao i prostore stranih država, orijentisali smo se i na domaći teren. Na njemu smo se još poodavno susreli sa činjenicom da jedan broj roditelja unutar Republike Srbije smatra da su im novorođenčad kradena iz porodilišta, iako su obaveštavani, najčešće usmeno, da su dotične bebe ili mrtvorođene ili pak umrle posle porođaja. Ovakav stav imali su najčešće zbog činjenice da im „mrtvorođenčad“ ili pak "naknadno umrla novorođenčad”, nisu po „događaju“ predavana, ali im nije data ni adekvatna dokumentacija koja bi im rečeno potvrdila. Otuda su smatrali da se radi o specifičnom kriminalnom aktu nezakonitog oduzimanja deteta od roditelja, te da isti imaju pravo da se formirani problem razreši, a da se svako ono lice koje je u ovom kriminalnom aktu sudelovalo podvrgne adekvatnom kažnjavanju. Upravo zato što se takvim aktom povređuje ne samo njihovo pravo 
roditeljstva, jedno od osnovnih ljudskih prava, već i ista ta prava njihovih beba. Iz tih razloga, a zbog većeg broja roditeljskih prijava sa sumnjom da im je beba ukradena u porodilištu, startovao je i rad državnih institucija i ustanova. Pa je tako 20. jula 2005.g. formiran Anketni odbor Narodne skupštine sa zadatkom da utvrdi osnovanost ukazivanja Skupštini od strane više stotina roditelja da su im novorođenčad ukradena po porodilištima. Nakon sprovedenog postupka, Anketni odbor je došao do zaključka da su u radu opserviranih ustanova i službi često činjeni propusti. Iz tog razloga je formirao sledeće predloge, i to da se:

(1) izvrši deblokada rada MUP-a i pravosudnih organa;

(2) formira specijalizovana jedinica MUP-a sa zadatkom da istražuje slučajeve u vezi sumnje roditelja da su im deca nestala iz porodilišta;

(3) legislativnom rekonstrukcijom otkloni institut zastarelosti krivičnog gonjenja;

(4) uspostavi nadležnost specijalnog tužilaštva i specijalnog suda za borbu protiv organizovanog kriminala (i) u ovim slučajevima;

(5) ustali vršenje redovnog nadzora nad vođenjem, čuvanjem i arhiviranjem medicinske dokumentacije;

(6) jasno definišu procedure u slučaju smrti novorođenog deteta;

(7) uspostavi redovan nadzor nad radom matičnih službi, i

(8) usvoji zakon o DNK registru.

Narodna skupština Republike Srbije usvojila je Izveštaj o radu Anketnog odbora na sednici svog trećeg vanrednog zasedanja 14.07.2006. g. (Rakić Vodinelić, Ćurčić, 2014: 45).

Osim toga, 2006. g. je Ministarstvo unutrašnjih poslova Republike Srbije, u okviru Direkcije policije - Uprave kriminalističke policije, Rešenjem ministra unutrašnjih poslova, Odlukom br. 3252/2006-2, od 5 aprila 2006.g., formiralo Radnu grupu za istraživanje i proveru slučajeva nestanka dece iz porodilišta u Republici Srbiji, koja se potom i bavila ovim problemima. Obzirom na ozbiljnost materije kao i činjenicu da je moguće da su novorođenčad zaista kradena, čime se povređuju ljudska prava, istim problemom se bavio i Zaštitnik građana, koji o tome 2010.g. podnosi poseban izveštaj (Izveštaj zaštitnika građana o slučajevima tzv. „nestalih beba“ sa preporukama, 2010), jasno preporučujući da se za razrešavanje posmatranog problema, a zbog manjkavosti postojećeg zakonodavstva, formira poseban tome namenjen zakon.

O pojavi nestanka novorođenčadi, kao i potrebi adekvatnog pravnog pristupa razrešavanju dotičnog problema, na domaćem terenu, pored napred navedenih izvora, na specifičan način svedoči, primera radi, i članak autora Glavonjića (2020), u kome se tvrdi da je pred sudom u Strazburu 2013.g. bilo oko 100 tužbi roditelja iz Srbije koji sumnjaju da su im bebe ukradene u bolnicama i prodate imućnim parovima u Evropi i svetu nakon što su bez obrazloženja i medicinskih dokaza proglašene umrlim. Na moguću učestalost krađe novorođenčadi ukazuje i članak koji su objavile Novosti (2020). Takođe Vas upućujemo i na intervju Frederika 
Sundberga, koji je takođe obavio Zoran Glavonjić, u kome ovaj Šef Odeljenja za izvršavanje presuda Evropskog suda za ljudska prava iznosi činjenicu da je pred sudom u postupcima, započetim tokom 2019.g., čak 15 predmeta koji se odnose na krađu novorođenčadi u Srbiji, te da se sam problem uistinu može da reši samo usvajanjem posebnog zakona, tome namenjenog, od strane Republike Srbije (Sundberg, 2019).

O ozbiljnosti napred iznetih tvrdnji govore i neke neposredno utvrdive a neoborive činjenice. Primera radi da je samo iz Centra za socijalni rad Aleksinca nestalo čak 29 dosijea o usvajanju beba u vremenu 1976. - 1985 godina, kako to navodi Milutinović u tekstu za dnevni list Blic (Milutinović, 2019). U vezi ovog slučaja, u istom tekstu, Radiša Pavlović, član Vladine "Komisije za prikupljanje činjenica o statusu novorođene dece za koju se sumnja da su nestala iz porodilišta u Republici Srbiji” i predsednik "Udruženja za istinu i pravdu o bebama" rekao je novinaru Milutinoviću da smatra da su u aferu "očigledno umešani pojedinci zaposleni u bolnici, ali i u policiji i centru za socijalni rad”. Kako Pavlović kaže “jedan slučaj (je) počeo da odmotava klupko. Ovaj konkretan slučaj korene vuče još od 3. marta 1981.g., kada se na ginekološko-akušerskom odeljenju Opšte bolnice u Kruševcu porodila majka rodom iz okoline Aleksinca, koja ipak po svim dostupnim dokumentima i podacima uopšte ne postoji. Ubrzo nakon početka istraživanja shvatili smo da žena koja se vodi kao majka usvojenika uopšte ne postoji, ni pod devojačkim, ni pod venčanim prezimenom. Proveravali smo sva dostupna dokumenta uključujući i matičnu knjigu rođenih i došli do zaključka da majka koja se odrekla svog deteta i dala ga na usvajanje nikad nije ni postojala”. Slični prethodno uočenim problemima sa područija Aleksinca su i oni navedeni tokom emisije koju je vodio Martinović (2018.)", gde jedna od majki (navedena samo kao Mirjana) jasno kaže da je dete rodila u Višegradskoj ulici (Beograd) 1978. g., a da su joj lekari rekli da je dete umrlo ali njoj i suprugu nisu dozvolili da ga vidi, te da su nju otpustili iz bolnice sa dokumentacijom u kojoj se uopšte ne navodi porođaj ali ni novorođenče.

O utemeljenosti napred iznetih tvrdnji svedoči i činjenica da je u obrazloženju predloga zakona koji se odnosi na utvrđivanje statusa novorođene, a za koju se sumnja da su nestala iz porodilišta (Predlog Zakona o postupku utvrđivanja statusa novorođene dece za koju se sumnja da su nestala u porodilištima u Republici Srbiji, 2016), jasno rečeno da se smatra da je u vremenu od 1. januara 1970. godine pa do 9. septembra 2013. godine, zavisno od organa kojima su se roditelji obraćali, procenjivano da se broj ukradenih beba kreće od 350 do 650. Otuda ne čudi da su roditelji koji tvrde da im je beba ukradena iz porodilišta tražili da se donese zakon koji bi to tretirao na odgovarajući način. Šta više to je traženo i odlukom Evropskog suda za ljudska prava u slučaju Zorica Jovanović protiv Srbije (European Court for Human Rights, Second Section, Case of Zorica Jovanović v. Serbia, 2013). Iz tog razloga je već 2014. godine urađen tekst nacrta takvog zakona, mada ne od oficijelnih državnih organa već pripadnika pravne nauke i struke. I to prilično obiman tekst koji je za regulisnje nekih pitanja pružao i različite varijante tome namenjenih normi (Rakić Vodinelić, Ćurčić, 2014). Šta više, obzirom da sama Država nije pokrenula adekvatan postupak formiranja takvog zakona to je i od Komiteta ministara Saveta Evrope, tačnije njegovog Sekretarijata, više puta traženo 
njegovo formiranje. Na primer na njegovom 1250 skupu (8-10. 03. 2016), kada je od Republike Srbije ponovo zahtevano da formira specijalni zakon kojim može da se uspostavi poseban istražni mehanizam za rešavanje slučajeva nestalih beba (Committee of Ministers, Secretariat Genral,). Jasno, ovaj zahtev je baziran na principijelnim elementima presude Evropskog suda za ljudska prava u slučaju Zorica Jovanović protiv Srbije. Samim tim smatramo da je ova presuda, kao svojevrstan case-study tekst, od velikog značaja i za naš pristup problemu potrebe i mogućnosti pravnog sagledavanja i tretmana nestanka beba u Republici Srbiji, te bi o njoj, koliko je to moguće sažeto, izložili pre nego li pređemo na sam proces sagledavanja uočenih problema zakonskog i praktičkog pristupa nestanku beba.

\subsubsection{Slučaj Zorica Jovanović protiv Srbije}

Predmet Zorica Jovanović protiv Srbije (European Court for Human Rights, Second Section, Case of Zorica Jovanović v. Serbia, 2013) je, kako se to vidi iz dostupne presude, formiran "na osnovu predstavke (broj 21794/o8) protiv Republike Srbije koju je Sudu (Zorica Jovanović) podnela "prema članu 34. Konvencije za zaštitu ljudskih prava i osnovnih sloboda... dana 22. aprila 2008. godine (str. 2.)". U okviru postupka sud je, obrađujući "Okolnosti predmeta" utvdio i naveo posebne činjenice:

"Podnositeljka predstavke... 28. oktobra 1983. godine (je), u Medicinskom centru u Ćuprïi (MCĆ), državnoj ustanovi, rodila zdravog dečaka”.

"U periodu od 28. do 3o. oktobra 1983. godine, dok je još bila u MCĆ, podnositeljka predstavke (je)... redovno viđala svog sina”.

"Lekari su podnositeljku predstavke 3o. oktobra 1983. godine obavestili da će i ona i njen sin sutradan biti otpušteni iz bolnice."

"Dežurni lekar je 31. oktobra 1983. godine, oko 6.30 časova, obavestio (je) podnositeljku predstavke da je „njena beba preminula“. Pošto je to čula, podnositeljka predstavke je odmah otrčala niz hodnik, ka prostorịi gde je njen sin proveo noć. Nju su, međutim, fizički sprečila dva dežurna lica... Članovima njene porodice je kasnïje rečeno da će obdukcïa novorođenčeta biti obavljena u Beogradu, zbog čega njegovo telo još ne može da se preda roditeljima. Podnositeljka predstavke i njena porodica ostali su zbunjeni zbog čega obdukcija mora da se obavi u Beogradu, jer je bilo jasno odstupanje od uobičajene prakse $M C C^{\prime}$.

"Počev od 2001. godine, a posebno od 20o2. godine, srpski mediji su počeli da izveštavaju o brojnim slučajevima kao što je slučaj podnositeljke predstavke (vidi, na primer, na http://www.kradjabeba.org, infomacija od 29. januara 2013. godine)".

"Podnositeljka predstavke je 24. oktobra 20o2. godine uputila zahtev MCĆ, tražeći svu relevantnu dokumentaciju u vezi sa smrću njenog sina”.

"Podnositeljka predstavke je 12. novembra 20o2. godine obaveštena od strane MCĆ da je njen sin preminuo 31. oktobra 1983. godine, u 7.15 časova, $i$ da je 
njegova smrt surstana kao "exitus non sigmata", tj. kao smrt bez naznake uzroka. MCĆ je ostao pri stavu da nema drugih informacija pošto je njegova arhiva u međuvremenu poplavljena i mnoga dokumenta su uništena”.

“Opština Ćuprija je 22. novembra 20o2. godine obavestila podnositeljku predstavke, kao odgovor na njen zahtev, da je rođenje njenog sina registrovano u opštinskoj evidenciji, a da smrt nije”.

"Suprug podnositeljke predstavke, a otac deteta, je 1o. januara 2003. godine podneo krivičnu prïavu Opštinskom javnom tužilaštvu u Ćupriji. Prijava je podneta protiv medicinskog osoblja MCĆ, koje je podnositeljka predstavke smatrala odgovornim za „otmicu njenog sina“".

"Pomenuto tužilaštvo je 15. oktobra 20o3.g. odbacilo prijavu podnositeljke predstavke (uistinu ne njenog supruga, stvarnog podnositelja, prim. V. J.) kao nepotkrepljenu dokazima, pošto „nije bilo dokaza da je njen sin preminuo 31. oktobra 1983. godine“. Dalje obrazloženje nije dato i nije bilo naznake da li je obavljena prethodna istraga”.

"Opština Ćuprija je 19. septembra 2007. godine poturdila da smrt sina podnositeljke predstavke nije nikada zvanično registrovana”.

"Kao odgovor na njen raniji zahtev, Opština Ćuprija je 28. decembra 2007. godine dostavila podnositeljki predstavke kopije izvoda iz matične knjige rođenih njenog sina, kao i zahtev MCĆ za njegovu prijavu”.

"Telo podnositeljkinog sina nikada nije preneto podnositeljki predstavke niti njenoj porodici. Oni nikada nisu dobili ni izveštaj o obdukciji niti su obavešteni kada i gde je on navodno sahranjen".

Na dalje Sud za ljudska prava u Predmetu Zorica Jovanović protiv Srbije je konstatovao:

“(Da su se) Stotine roditelja u situacīi kao što je podnositeljkina, tj. čije su bebe „nestale“, posle navodne smrti u bolničkim odeljenjima, uglavnom sedamdesetih, osamdesetih i devedesetih godina prošlog veka, obratile 2005. godine Skupštini Srbije tražeći obeštećenje”.

“(Da je) Skupština... 14. jula 20o6. godine zvanično usvojila izveštaj koji je pripremio Anketni odbor. Nalazi ovog izveštaja uključivali su, između ostalog, da: (a) je bilo ozbiljnih nedostataka u važećem zakonodavstvu u relevantnom trenutku, kao i u postupcima pred državnim organima i zdravstvenim ustanovama; (b) ova sitacija... opravdava sumnje/brige roditelja oko toga šta se stvarno desilo sa njihovom decom; (c) nikakva krivično-pravna zaštita sada ne bi bila delotvorna zbog važećih odredbi o zastarelosti; i (d) (da su) istovremeni napori svih Vladinih tela, kao i izmene relevantnog zakonodavstva... neophodni kako bi roditelji dobili odgovarajuće obeštećenje”.

Potom Sud, pod brojem 35, jasno navodi koje su norme važećeg Krivičnog zakonika Republike Srbije povređene u vreme donošenja presude, to jest članovi: 191, 192, 388. i 389 (Krivični zakonik, Sl. glasnik $R S$, br. 85/2005, 88/05, 107/05, 72/o9 i 111/2009). A takođe, pod brojem 36, naglašava da, po osnovu 
Zakona o obligacionim odnosima (Sl. glasnik RS, br. 128/2020), njegovim članovima 199. i 200, "svako ko je pretrpeo strah, fizički bol ili zapravo duševnu patnju kao posledicu kršenja njegovog ili njenog „prava ličnosti“ ima pravo, u zavisnosti od njihovog trajanja i jačine, da pokrene postupak za finansijsku naknadu pred parničnim sudovima i, osim toga, da traži druge oblike obeštećenja „koja bi mogla“ da pruže odgovarajuće nematerijalno zadovoljenje”. $\mathrm{Na}$ dalje, a pod brojem 38, i da član 377. navedenog zakona (u stavu 1.) "propisuje da ako je do predmetne štete došlo kao posledica učinjenog krivičnog dela, rok zastarelosti za parnični postupak može se produžiti tako da odgovara važećem roku zastarelosti za krivični postupak".

Šta više, a pod br. 42., Sud za ljudska prava ukazuje da "Tužena država kontinuirano nije pružala bilo kakve informacije o sudbini (tužiteljkinog) sina, zbog čega, pod brojem 43, jasno kaže da "Sud smatra da bi ovu pritužbu trebalo razmatrati prema članu 8. Konvencije, koja odredba, u relevantnom delu, glasi kako sledi: „Svako ima pravo na poštovanje svog ... porodičnog života...”; “Javne vlasti neće se mešati u vršenje ovog prava sem ako to nije $u$ skladu sa zakonom i neophodno $u$ demokratskom društvu u interesu nacionalne bezbednosti, javne bezbednosti ili ekonomske dobrobiti zemlje, radi sprečavanja nereda ili kriminala, zaštite zdravlja ili morala, ili radi zaštite prava i sloboda drugih."

Sud, pod brojem 48 presude, jasno kaže da "Ako se vratimo na predmetni slučaj, Sud primećuje da je sin podnositeljke predstavke navodno umro/nestao 31. oktobra 1983. godine, dok je Konvencija stupila na snagu u odnosu na Srbiju 3. marta 2004. godine. Međutim, navodni propust Tužene države da podnositeljki predstavke pruži bilo kakve konačne i/ili pouzdane informacije o sudbini njenog sina nastavio se do danas. U takvim okolnostima Sud smatra da se pritužba podnositeljke predstavke odnosi na trajnu situaciju”. Otuda, pod brojem 49, i da se primedba Vlade Republike Srbije “da ne postoji nadležnost Suda ratione temporis mora odbiti”.

Pod brojem 62 Sud konstatuje da je suprug podneo relevantnu krivičnu prijavu, ali da je "ovu prijavu..., međutim, odbacilo Javno tužilaštvo, bez naznake da li je sprovedena prethodna istraga".

Otuda, u okviru "Zaključka", pod br. 65, "Sud konstatuje da pritužba podnositeljke predstavke nije očigledno neosnovana u okviru značenja člana 35. stava 3, pod (a) Konvencije (te da) ona takođe nije nedopuštena ni po kom drugom osnovu, i zbog toga (da) se mora proglasiti dopuštenom", a pod brojem 66 da je "Podnositeljka predstavke... ponovo potvrdila svoju pritužbu zbog toga što joj Tužena država nije u kontinuitetu pružala informacije o stvarnoj sudbini njenog sina (kao i da)".... ako je njen sin umro kao što je tvrdio MCĆ, da je njegova smrt trebalo da bude prijavljena nadležnim opštinskim organima, da telo bude pokazano roditeljima, i da bude izdat izveštaj o obdukciji”.

Uzimajući sve prethodno izrečeno u obzir Sud je, pod brojem 92, jasno kazao da "obzirom na gore navedeno, kao i na značajan broj potencijalnih podnosilaca predstavki, Tužena država mora, u roku od godinu dana od datuma kada ova presuda postane pravnosnažna, u skladu sa članom 44. stav 2. Konvencije, preduzeti sve odgovarajuće mere, po mogućstvu putem lex specialis-a... da osigura 
uspostavljanje mehanizma sa ciljem obezbeđenja pojedinačnog obeštećenja svim roditeljima u situaciji kao što je ili koja je dovoljno slična situaciji podnositeljke predstavke... Ovaj mehanizam bi trebalo da nadzire nezavisno telo, sa odgovarajućim ovlašćenjima, koje će moći da pruži pouzdane odgovore u vezi sa sudbinom svakog deteta i pruži odgovarajuću naknadu, prema slučaju".

"Iz svih navedenih razloga Sud je jednoglasno (na str. 18)", pod brojem:

1. proglasio predstvaku dopuštenom,

2. utvrdio da je došlo do povrede člana 8. Konvencije,

Te pod brojem 4 utvrđuje:

(a) da Tužena država treba da plati podnositeljki predstavke, u roku od tri meseca od datuma kada presuda postane pravosnažna, u skladu sa članom 44. stav 2. Konvencije, sledeće iznose, koji će se pretvoriti u srpske dinare po stopi važećoj na dan izmirenja: (i) 10.000 evra (deset hiljada evra), plus svaki porez koji se može naplatiti, na ime nematerijalne štete; (ii) 1.800 evra (hiljadu osam stotina evra), plus svaki porez koji se može naplatiti podnositeljki predstavke, na ime troškova;

(b) da po isteku gore navedena tri meseca do isplate, treba platiti običnu kamatu na gore navedene iznose po stopi koja je jednaka najnižoj kamatnoj stopi Evropske centrale banke u zakonskom periodu uz dodatak od tri procentna poena.

6. utvrđuje da Tužena država mora, u roku od godinu dana od datuma kada ova presuda postane pravosnažna, u skladu sa članom 44., stavom 2. Konvencije, preduzeti sve odgovarajuće mere sa ciljem uspostavljanja mehanizma za obezbeđenje pojedinačnog obeštećenja svim roditeljima u situaciji kao što je ili koja je dovoljno slična situaciji podnositeljke predstavke (pozivajući se na stav br 92. Presude)".

No, kako se to moglo iz našeg izlaganja na prethodnim stranicama da vidi, iako smo bili u obavezi da već 2014. godine formiramo zakon neophodan za adekvatan tretman slučajeva nestalih beba, u suštini njihovih otmica, te da isti tada stupi na snagu, rad na zahtevanom legislativnom aktu se odvijao veoma sporo i sa puno grešaka. Smatramo da smo ih utvrdili i u sada aktuelnom tekstu Zakona o utvrđivanju činjenica o statusu novorođene dece za koju se sumnja da su nestala iz porodilišta u Republici Srbiji.

4.2. Procese sagledavanja problema nestalih beba i Zakon o utvrđivanju činjenica o statusu novorođene dece

Problem nestajanja beba je decenijama prisutan unutar brojnih država sveta, ne samo Republike Srbije. Ali na našem prostoru dugo vremena nije adekvatno posmatran, iako su brojni roditelji ukazivali na to da su njihove bebe nestajale iz porodilišta, uz obrazloženja, često samo usmena, da su novorođenčad umrla. A pri tom u mnogo slučajeva ista roditeljima nisu predavana. Otuda je tek „Predmet Zorica Jovanović protiv Srbije “ i na našem terenu pokrenuo ozbiljnija razmatranja o potrebi ispunjenja obaveza iz Evropske Konvencije o zaštiti ljudskih sloboda i 
osnovnih prava, ali i drugih konvencija od značaja za zaštitu ovih prava. To je dovelo i do formiranja oficijelnog Predloga Zakona o utvrđivanju činjenica o statusu novorođene dece za koju se sumnja da su nestala iz porodilišta u Republici Srbiji, što je 2020. godine rezultovalo i njegovim donošenjem (Zakon o utvrđivanju činjenica o statusu novorođene dece za koju se sumnja da su nestala iz porodilišta u Republici Srbiji, Sl. glasnik RS, br. 18/2020). Primarni cilj ovoga Zakona, po osnovu njegovog člana 2., stava 1., je „utvrđivanje činjenica pogodnih da se utvrdi istina o statusu novorođene dece za koju se sumnja da su nestala iz porodilišta u Republici Srbiji, na osnovu dokaza koji se izvedu i podataka koji se prikupe u sudskom postupku od državnih i drugih organa, roditelja i drugih lica“. Dotični zakon je, iako relativno kratak, dosta složene i kvalitetne strukture. Ali, mišljenja smo, i opterećen izvesnim manjkavostima, pa čak i greškama koje su u suprotnosti sa osnovnim elementima po našem Ustavu usvojenih legislativnih akata međunarodnog prava. Upravo onih na koje smo ukazali na prethodnim stranicama. Iako se radi o malom broju članova posledice nisu ni malobrojne, ali ni male niti jednostavne. Pogađaju, pre svega, prava roditelja i novorođenčadi te dece, ali i mogućnosti zakonitog rada državnih organa koji bi trebalo da im pruže adekvatnu zaštitu, uključujući, u finalu, ako to zatreba, i krivično-pravnu.

Problemi koje smo uočili unutar ovog Zakona proizilaze iz njegovih članova 17. i 29. u ukazivanju na njih krenimo od Cllana 17. - Rok za podnošenje predloga, koja norma propisuje da se „predlog za utvrđivanje činjenica o statusu novorođenog deteta za koje se sumnja da je nestalo iz porodilišta u Republici Srbiji podnosi „sudu $\mathrm{u}$ roku od šest meseci od dana stupanja na snagu ovog zakona². Ovo vremensko ograničavanje mogućnosti zaštite ljudskih i građanskih prava je u suprotnosti sa principima Povelje Ujedinjenih nacija, ali i normama Univerzalne deklaracije o ljudskim pravima, te Međunarodnog pakta o građanskim i političkim pravima, Konvencije Ujedinjenih nacija o pravima deteta kao i Konvencije o građanskopravnim aspektima međunarodne otmice dece, o čemu je u logičkom bloku ovog teksta, pod br. 3.1.1.. detaljno izlagano. Šta više, odredba iz čl. 17. Zakona je očigledno neustavna jer je svojom logičkom konstrukcijom (ne samo vremenskim ograničenjem) protivna odredbama iz članova: 3., 16., 18., 26., 36., 56., 64. i 194. Ustava Republike Srbije, ali i normama Konvencije Ujedinjenih nacija o pravima deteta, Konvencije o građanskopravnim aspektima međunarodne otmice dece kao i Međunarodne konvencije za zaštitu svih lica od prisilnih nestanaka, a koji su legislativni tekstovi sada deo zakonodavstva Republike Srbije normativnohijerarhijski ispod Ustava ali iznad Zakona o utvrđivanju činjenica o statusu novorođene dece za koju se sumnja da su nestala iz porodilišta u Republici Srbiji. I to tekstovi koji ni jednom svojom normom vremenski ne ograničavaju zaštitu prava dece i njihovih roditelja. Samim tim je uvođenje vremenskog ograničenja, putem Člana 17. - Rok za podnošenje predloga, jasno neustavano ali i protivno navedenim konvencijama kao gradivnim elementima mozaika važećeg zakonodavstva

${ }^{2}$ Vidi: Zakon o utvrđivanju činjenica o statusu novorođene dece za koju se sumnja da su nestala iz porodilišta u Republici Srbiji, “Deo 2. - Pokretanje postupka”, „Član. 15. - Predlagač“, st. 1., a posebno „Član 17.- Rok za podnošenje predloga“. 
Republike Srbije. Otuda i pravno nevaljano te ga valja, kao takav, izbaciti iz dotičnog Zakona. Ali ukoliko bi dotični član opstao to automatski vremenski ograničava, šta više, blokira mogućnost njihove praktiče primene. Time se uistinu vrši dalja, i to teška, povreda ljudskih građanskih i socijalnih prava! I to kako roditelja tako i dece. Ali i krivično-pravna povreda, mada ne i samo ona.

$\mathrm{Na}$ ovom mestu ukazujemo da nas u našoj analizi navedene konvencije takođe obavezuju i da prava koja iste štite zaštićujemo normama kaznenog prava. Uistinu povređivanje njihovih normi može da se iskaže kao neko od krivičnih dela iz Krivičnog zakonika Republike Srbije. I to kao krivično delo iz: „Čl. 191. Oduzimanje maloletnog lica“, „Čl. 192. - Promena porodičnog stanja“, „Čl. 388.Trgovina ljudima (st. 7.)“ te „Čl. 389. - Trgovina maloletnim licima radi usvojenja“.

Svaki od navedenih delikata pripada kategoriji trajnih krivičnih dela. Kao takvo smatra se da je adekvatno tretirano ukoliko se otkrije izvršilac, ili izvršioci, te podvrgne krivičnom postupku. Otuda je jasno da se ni pravo na krivični progon počinilaca navedenih krivičnih dela ne može uopšte ograničiti, pa ni vremenski, kako je to učinjeno članom 17. Zakona o postupku utvrđivanja činjenica o statusu novorođene dece za koju se sumnja da su nestala u porodilištima u Republici Srbiji.

$\mathrm{Na}$ šta na ovom mestu takođe ukazujemo? Sam akt nezakonitog oduzumanja novorođenčeta, iako može biti izvršen samo od jedne osobe, u stvarnosti je gotovo uvek ne jedno krivično delo i ne izvršeno od samo jednog lica već od više osoba, putem niza posebno inkriminsanih radnji. Kao takvo karakterišu ga, bilo samostalno ili u kombinaciji, radnje sledećih krivičnih dela iz važećeg Krivičnog zakonika Republike Srbije: „Člana 33. - Saizvršilaštvo“, jer se oduzimanje novorođenčeta najčešće izvršava od strane više osoba, ne samo one koja ga fizički oduzima već i onih koje istu pomažu na različite načine, „Člana 34. - Podstrekavanje“, obzirom da osoba koja želi da na nezakonit način dođe do novorođenčeta podstrekava druga lica da joj u tome, u različitim fazama izvršenja delikta, pomognu, „Člana 35. Pomaganje“, obzirom da se za izvršavanje delikata iz članova: 191., 192., 388. i 389. traži pomoć, najčešće više od jedne osobe, od kojih su neke osobe na službenim funkcijama, „Člana 355. - Falsifikovanje isprave“, službenog akta neophodnog za uspostavljanje lažnog roditeljskog statusa u odnosu na uistinu nezakonito oduzeto novorođenče, ali i „Člana 356. - Posebni slučajevi falsifikovanja isprave“, „Člana 357. - Falsifikovanje službene isprave“, „Člana 358. - Navođenje na overavanje neistinitog sadržaja“, „Člana 359. - Zloupotreba službenog položaja“, te „Člana 361. Nesavestan rad u skužbi“.

Nezakonito oduzimanje novorođenčeta je uistinu protivzakoniti, krivično-pravno jasno definisani a složeni akt. Akt koji karakteriše sticaj više prethodno navedenih krivičnih dela. Otuda je logično da se ista podvrgnu adekvatnom tretmanu, što znači ne samo navedenim normama već i za to upotrebljivoj metodologiji. Ali da li je to po osnovu člana 17. Zakona o utvrđivanju činjenica o statusu novorođene dece za koju se sumnja da su nestala iz porodilišta u Republici Srbiji izvodljivo? Njegovim formiranjem dotični legislativni akt svojom logikom i sadržinom nije usklađen sa metodologijom: Međunarodne organizacije za migracije (International Organization for Migration - IOM), na čije metode i ciljeve rada je ukazano još 1952. u tzv. 
„Tajnom izveštaju” (Confidential Report on the Conference on Migration, Held at Brussels, December, 5 1951), Visokog komesarijata Ujedinjenih nacija za izbeglice (United Nations High Commissioner for Refugees - UNHCR, kancelarija UN kreirana 1950.g.), formirane Rezolucijom Generalne skupštine UN 319 (IV, 1950) [General Assembly Resolution 319 (IV): Provisions for the functioning of the High Commissioner's Office for Refugees, August 16, 1950], i Kancelarije Visokog komesarijata Ujedinjenih nacija za ljudska prava (Office of the United Nations High Commissioner for Human Rights, UN GA Res. 48/141, 1993), organizacija čiji je član i Republika Srbija: Otuda i u obavezi primene njihovih metodologija. Metodologija koje ne omogućavaju vremensko ograničenje pristupanju podnošenja predloga za utvrđivanje činjenica o statusu novorođenog deteta za koje se sumnja da je nestalo iz porodilišta.

Odredba člana 17. Zakona takođe ne ispunjava ni standarde Programa prekograničnih mehanizama upućivanja za žrtve trgovine ljudima (European Commission: Transnational Referral Mechanism Model - TRM, 2017), a povređeni su i ne primenjuju se ni TRM standardi koji podržavaju osnovne principe na kojima počiva Konvencija o pravima deteta. Posebno je reč je o sledećim principima uočivim unutar ove Konvencije: prava deteta na život, opstanak i razvoj (čl, 7., st. 2.); nediskriminacije (očigledna iz člana 8.); i najboljih interes deteta (očuvanje interesa deteta je očito iz članova 8. i 9.); i participacije (čl. 9., st. 2.).

Da pojasnimo. Zakon mora da tretira ravnopravno svu decu, živo rođenu i onu rođenu pod nerasvetljenim okolnostima, bez bilo kog oblika diskriminacije.

Zakon, ni u obliku u kom je stupio na snagu, ne zadovoljava zahtev principa pridržavanja najboljeg interesa deteta, samim tim što propisuje vremensko ograničenje (iz člana 17.) u okviru koga se može da pristupi radnjama koje bi dovele do zadovoljenja najboljeg interesa deteta. U slučaju kada položaj deteta nije rasvetljen, interes je deteta da se utvrdi da li je živo i ako jeste živo kod koga se nalazi!

Zakon takođe ne zadovoljava ni princip participacije iz čl. 9., st. 2. Konvencije o pravima deteta, kojim je jasno propisano da ce „u svakom postupku, u skladu sa njegovom tačkom 1., sve zainteresovane strane dobiti priliku da učestvuju u postupku i da iznesu svoje mišljenje“. A pod pojam „svaka zainteresovana strana“ ulaze ne samo roditelji deteta već i samo dete, ali i najbliži srodnici.

Ima li još propusta unutar Zakona o postupku utvrđivanja činjenica o statusu novorođene dece za koju se sumnja da su nestala u porodilištima u Republici Srbiji?

Republika Srbija je 2019.g. donela Akcioni plan za sprovođenje Strategije prevencije i suzbijanja trgovine ljudima, posebno ženama i decom i zaštite žrtava za 2019. i 2020. Godinu (Sl. glasnik RS, br. 50/2019). Ovaj akt obavezuje, pod brojem:

- 7., na poboljšanje identifikacije i samoidentifikacije žrtava,

- 8.1. na dosledno poštovanje ljudskih prava žrtava i primene međunarodnih standarda zaštite ljudskih prava žrtava trgovine ljudima, u borbi protiv trgovine ljudima, te 
- 8.2. na unapređivanje propisa u svrhu efikasnije zaštite žrtve i omogućavanja otkrivanja, procesuiranja i sankcionisanja izvršilaca krivičnog dela trgovine ljudima.

I ovi napred navedeni elementi nas upućuju na neophodnost poštovanja obaveza formiranih u okviru Fakultativnog Protokola uz Konvenciju o pravima deteta o prodaji dece (Optional Protocol to the Convention on the Rights of the Child on the sale of children, child prostitution and child pornography, 2000), inače preuzetih ratifikacijom (Zakon o potvrđivanju Fakultativnog protokola o prodaji dece, dečijoj prostituciji i dečijoj pornografiji, uz Konvenciju o pravima deteta, Sl. list SRJ Međunarodni ugovori, br. 7/2002), koji Protokol, članom 2., stavom 1., pod (a), jasno propisuje da se pod „prodajom dece“ podrazumeva bilo koja radnja kojom bilo koje lice, ili grupa lica, prebaciju neko dete nekom drugom, za novčanu ili bilo koju drugu naknadu. Kao što vidimo i ovaj međunarodno pravni legislativni akt obavezuje na podizanje kvaliteta zakonodavstva, ali i kvaliteta njegove primene, $\mathrm{u}$ cilju zaštite od nezakonitog oduzmanja novorođenčadi.

U našoj analizi ukazujemo Vam i da Zakon o postupku utvrđivanja činjenica o statusu novorođene dece za koju se sumnja da su nestala u porodilištima u Republici Srbiji, svojim „Delom 5. - Komisija“, njegovim članom 29., stavom 1., obavezuje Vladu Republike Srbije da u roku od 30 dana od početka primene ovog Zakona obrazuje Komisiju za prikupljanje činjenica o statusu novorođene dece za koju se sumnja da su nestala iz porodilišta u Republici Srbiji (u daljem tekstu: Komisija). Po osnovu stava 2. člana 29. Zakon jasno propisuje da je ,zadatak Komisije... da prikuplja i obrađuje sve činjenice i podatke koji se nalaze u posedu:

1) pravosudnih organa pred kojima su vođeni ili se još uvek vode pretkrivični i krivični postupci pokrenuti po krivičnim prijavama roditelja ili drugih osoba, a koja sadrže navode o oduzimanju i trgovini sa novorođenom decom;

2) organa unutrašnjih poslova koji su ili kroz primenu policijskih ovlašćenja ili postupajući po nalozima pravosudnih organa zaduženih za vođenje pretkrivičnih i krivičnih postupaka, ili na drugi način, došli u posed činjenica, podataka i saznanja koji se odnose na oduzimanje i trgovinu novorođenom decom;

3) svih medicinskih ustanova koje su u svom radu ili na bilo koji drugi način došle ili su mogle da dođu u kontakt sa trudnicama, novorođenom decom ili decom koja su mrtvorođena, ili decom koja su ubrzo nakon porođaja preminula u medicinskim ustanovama;

4) matičnih službi jedinica lokalne samouprave u koje su upisivane činjenice rođenja i smrti sve dece za koje postoji sumnja da su oduzeta i da se sa njima trgovalo;

5) svih javnokomunalnih preduzeća kojima je bilo ili još uvek jeste delegirano javno ovlašcenje sahranjivanja pogrebnih ostataka mrtvorođene dece ili dece koja su preminula ubrzo nakon porođaja u nekoj od medicinskih ustanova;

6) svih centara za socijalni rad koji bi u svom posedu mogli da imaju činjenice, podatke i saznanja koja se odnose na oduzimanje i trgovinu novorođenom decom; 
7) svih drugih državnih, pokrajinskih organa, kao i organa jedinica lokalne samouprave, i svih javnih preduzeća i ustanova koje bi u svom posedu mogle da imaju činjenice, podatke i saznanja koji se odnose na oduzimanje i trgovinu novorođenom decom“.

Dakle, zadatak i ovlašćenje Komisije je samo da prikuplja i obrađuje ove podatke, a jedina obaveza je, kako to propisuje član 29. stavom 9., da „podnosi godišnji izveštaj o svom radu Vladi i nadležnom odboru Narodne skupštine“. I ništa više od toga! Jasnije rečeno, Komisiji uopšte nisu data bilo kakva regulatorna ovlašćenja prema državnim organima, ustanovama, službama, javnim preuzećima i centrima (npr. za socijalni rad), koji bi subjekti prava u svom posedu mogli da imaju činjenice koje se odnose na oduzimanje i trgovinu novorođenom decom, a koji su podaci potrebni da bi se zaista, i to vremenski neograničeno, zaštitila prava dece za koju se sumnja da su oduzeta od porodilja! To jednostavno znači da, formalno-pravno i praktički gledano, ova Komisija, po osnovu člana 29., jeste svojevrsno debatno telo i ništa više! Ono što nas zaista začuđuje, Komisiji nije dato ovlašćenje da, ukoliko oficijelno dobije podatke koji upućuju na mogući protivzakoniti nestanak deteta, zahteva nastavljanje potrage za istim, i nakon prethodno ostvarenog sudskog epiloga. Time je njen rad, kao formalnog, zakonom osnovanog tela, a uspostavljenog u cilju zaštite ljudskih prava novorođenčadi i njihovih roditelja, tela na čije formiranje, zaduživanje i rad pozivaju napred analizirani legislativni akti međunarodnog prava, ograničen suprotno njihovim normama, i to da o događajima mogu jedino da ostvare saznanje i ništa više! Dake, Komisiji je onemogućena i po elementima ratifikovanih konencija obavezna proaktivna uloga, kao od Skupštine, putem zakona, osnovanog tela. A ista proaktivna uloga bi, po osnovu čl. 29., st., 2., t. 7., ali i dogradnje člana 29. adekvatnim stavom koji bi to omogućavao, morala da bude pravno moguća i da se uistinu ostvaruje. To znači da ima zakonsku mogućnost da, po osnovu svoje odluke povezane sa konkretnim slučajem, upućuje zahteve za adekvatno postupanje. Odluka bi mogla da se iskaže na tri načina, kao odluka da: je postupak konkretnog subjekta bio u skladu sa zakonom; je postupak konkretnog subjekta bio delimično u skladu sa zakonom, ili postupanje konkretnog subjekta nije bilo u skladu sa zakonom.

Jasno je da ukoliko Komisija donese odluke navedene pod brojevima 2 i 3 treba da ima ovlašćenje da zahteva adekvatno postupanje od subjekata, a naročito svih onih pobrojanih unutar člana 29., stava 2., t. 7. Zakona, a posebno ukoliko saznato ukazuje na moguće izvršenje nekog ili nekih od krivičnih dela, o kojima smo izlagali u ovom logičkom delu teksta.

Pored u članu 29., stavu 2. navedenih državnih organa, ustanova, službi, javnih preuzeća i centara, te pokrajinskih i lokalnih organa, smatramo da bi dogradnjom člana 29. valjalo da se na pružanje podataka od značaja za postupak utvrđivanja činjenica o statusu novorođene dece za koju se sumnja da su nestala u porodilištima u Republici Srbiji obavežu i druge institucije. Objasnimo.

Nedovoljna izgrađenost, ali i neusklađenost sa normama višeg ranga, od strane čl. 29. Zakona o postupku utvrđivanja činjenica o statusu novorođene dece za koju se 
sumnja da su nestala u porodilištima u Republici Srbiji, proizvodi i svojevrsne blokade drugih, a ne samo pobrojanih institucija. Koliko vidimo:

- Propušteno je da se Zakonom omogući da Komisija ostvari uticaj na postupanje Poverenika za informacije od javnog značaja i zaštitu podataka o ličnosti. Isti inače jeste ovlašćen, po zakonu (Zakon o slobodnom pristupu informacijama od javnog značaja, Sl. glasnik RS, br. 120/2004, 54/2007, 104/2009 i 36/2010), da utvrdi da li su informacije koje traže roditelji od značaja za postupak utvrđivanja činjenica o statusu novorođene dece za koju se sumnja da su nestala u porodilištima u Republici Srbiji. Ali Zakon o postupku utvrđivanja činjenica o statusu novorođene dece za koju se sumnja da su nestala u porodilištima u Republici Srbiji ne ovlašćuje Komisiju da Povereniku uputi zahtev u vezi podataka od značaja za utvrđivanje statusa novorođene dece, ali ni njegovog daljeg postupanja od značaja za dotični postupak.

- Propušteno je da se Komisiji omogući da ostvari uticaj na postupanje Zaštitnika građana. Zaštitnik građana je, između ostalog, ovlašćen i da pruža zaštitu pravima deteta. Postupa po sopstvenoj inicijativi kao i po pritužbi građana (usmenoj ili pismenoj). A trebalo bi da može da se u vezi konkretnog slučaja aktivira i po pritužbi Komisije za prikupljanje činjenica o statusu novorođene dece za koju se sumnja da su nestala iz porodilišta u Republici Srbiji. Zakon u sadašnjem obliku to ne omogućava. Zaštitinik građana treba da svojim postupanjem doprinese utvrđivanju činjenica o propisnom ili nepropisnom radu konkretnih organa i organizacija i da ukoliko utvrdi elemente nepropisnog postupanja upozori na uočene povrede i zatraži njihovu ispravku. Šta više, i da, ukoliko se ne postupi po njegovom zahtevu, na isti problem upozori Skuštinu ali i Vladu Republike Srbije.

- Propušteno je da se Zakonom omogući da Komisija ostvari uticaj na postupanje Nacionalnog kordinatora za borbu protiv trgovine ljudima, iako je logično da je, po osnovu Strategije za borbu protiv trgovine ljudima i Akcionog plana (tač. 7.1.1.) Nacionalni kordinator (prvi put imenovan 6. oktobra 2017.g.) nadležan i da daje mišljenje o postupanju državnih organa, pa tako i onih činjenja od značaja za utvrđivanje trgovine ljudima, i idetifikaciju žrtava ove trgovine, pa tako i novorođenčadi kao takvih žrtava. Takođe je nadležan i da kontaktira: ministarstva, među njima i ministarstvo: zdravlja, pravde, socijale, spoljnih poslova, unutrašnjih poslova, ali i Službu za kordinaciju zaštite žrtava trgovine ljudima Centra za zaštitu žrtava trgovine ljudima, I Posebnu radnu grupu za sprovođenje i praćenje Strategije prevencije i suzbijanja trgovine ljudima, posebno ženama i decom i zaštite žrtava 2017-2022 (formirane 2017), koja je obrazovana posebnim rešenjem (Rešenje ministra unutrašnjih poslova o obrazovanju Posebne radne grupe za sprovođenje i praćenje Strategije prevencije i suzbijanja trgovine ljudima, posebno ženama i decom i zaštite žrtava, 2018. godine), Kancelariju za koordinaciju aktivnosti u borbi protiv trgovine ljudima (unutar Direkcije policije), čije je, inače, Nacionalni koordinator za borbu protiv trgovine ljudima rukovodilac, i Ministarstvo za ljudska i manjinska prava i društveni dijalog (Zakon o ministarstvima, Sl. glasnik RS, br. 128/2020, čl. 12.), čiji rad na ovom polju dopunjava i rad Sektora za 
ljudska i manjinska prava i slobode Ministarstva državne uprave i lokalne samouprave (Zakon o ministarstvima, čl. 11.), i Savet za borbu protiv trgovine ljudima, osnovan posebnom odlukom kao Savet Vlade (Odluka o obrazovanju Saveta za borbu protiv trgovine ljudima, 2017.g).

- Propušteno je da se Zakonom omogući da Komisija ostvari uticaj na uspostavljanje i upravljanje bazom genetičkih podataka od značaja za utvrđivanje statusa dece.

Ukoliko se u rekonstrukciji Zakona usvoje izmene kojima bi se ispravili uočeni nedostaci koji se tiču mogućnosti prokativnog rada Komisije tada bi posmatrani Zakon o utvrđivanju činjenica o statusu novorođene dece za koju se sumnja da su nestala iz porodilišta u Republici Srbiji bio daleko višeg kvaliteta, te omogućio stvarno utvrđivanje šta se i kako dešavalo sa novorođenčadi u brojnim slučajevima, slučajevima koji su se dešavali ali se odigravaju i u aktuelnom vremenu.

\section{ZAKLJUČCI - ŠTA ČINITI?}

Da bi se bebe zaštitile od nezakonitog nestajanja iz porodilišta Republike Srbije, kao i omogućilo njihovo zakonito vraćanje roditeljima, neophodno je da se izvrše izvesne izmene unutar Zakona o utvrđivanju činjenica o statusu novorođene dece za koju se sumnja da su nestala iz porodilišta u Republici Srbiji. Takve koje ce uistinu omogućiti da se praktički angažuju za to sve potrebne institucije i organi. A samim tim i omogućila primena normi Krivičnog zakonika iz članova: 33, 34, 35, 191, 192, $356,357,358,359,361,388$. i 389 .

Prva izmena koju predlažemo izvršila bi se ukidanjem vremenskog ograničenje za podnošenje Predloga za utvrđivanje činjenica o statusu novorođenog deteta za koje se sumnja da je nestalo iz porodilišta u Republici Srbiji, to jest ukidanjem Člana 17. - Rok za podnošenje predloga.

Druga izmena za koju se zalažemo, a jeste od značaja za stvarno zaživljavanje Zakona o utvrđivanju činjenica o statusu novorođene dece za koju se sumnja da su nestala iz porodilišta u Republici Srbiji tiče se prerade njenog člana 29., stava 1. Tačnije njegovog dopunjavanja u okviru spiska institucija, organa i ustanova od značaja za zaista potpuno sagledavanje i razrešavanje slučajeva prema kojima postoji pretpostavka da su deca nezakonito nestala iz porodilišta. Pored postojećih sedam tačaka stava 2. člana 29. Zakona valjalo bi u ovaj stav uneti i tačke kojima bi kao izvor ovih informacija bili određeni i: Poverenik za informacije od javnog značaja i zaštitu podataka o ličnosti, Zaštitnik građana, Nacionalni kordinator za borbu protiv trgovine ljudima, ministarstva, među njima posebno ministarstvo: zdravlja, pravde, socijale, spoljnih poslova, i unutrašnjih poslova, Služba za kordinaciju zaštite žrtava trgovine ljudima Centra za zaštitu žrtava trgovine ljudima, posebna radna grupa za sprovođenje i praćenje Strategije prevencije i suzbijanja trgovine ljudima, posebno ženama i decom i zaštite žrtava 2017-2022.g., Kancelarija za koordinaciju aktivnosti u borbi protiv trgovine ljudima, Sektor za ljudska prava Ministarstva Ministarstva za ljudska i manjinska prava i društveni dijalog (utvrđen čl. 12. Zakona o ministarstvima, 2020.), koji je zamenio nekadašnju Kancelariju za ljudska i 


\author{
Zbornik IKSI, 1/2021 - V. Joldžić \\ „Potreba i mogućnosti pravnog sagledavanja i tretmana nestanka beba”, (str. 103-132)
}

manjinska prava (osnovanu Uredbom o Kancelariji za ljudska i manjinska prava, $S l$. glasnik RS, broj 75/2012), te Baza genetičkih podataka od značaja za utvrđivanje statusa dece3.

Treća izmena koju predlažemo, a jeste od značaja za stvarno zaživljavanje Zakona o utvrđivanju činjenica o statusu novorođene dece za koju se sumnja da su nestala iz porodilišta u Republici Srbiji, tiče se dodavanja novog stava, između sadašnjih 8. i 9., člana 29. Stava kojim bi se ovlašćenja Komisije proširila u skladu sa u logičkom bloku 5. ovog teksta objašnjenim viđenjima. Dotičnim stavom valjalo bi da se Komisija ovlasti da po dobijanju podataka iste obradi, ali i na bazi istih donese odluku a kojom utvrđuje da je: postupak konkretnog subjekta bio u skladu sa zakonom; postupak konkretnog subjekta bio delimično u skladu sa zakonom, ili postupanje konkretnog subjekta bilo u suprotnosti sa zakonom.

Četvrta izmena za koju se zalažemo ticala bi se unošenja stava kojim bi se Komisija ovlastila da, ukoliko donese odluke navedene pod brojevima 2. i 3., zahteva adekvatno postupanje od subjekta pobrojanih unutar člana 29., stava 2., t. 7., kao i onih za čije angažovanje se zalažemo, postupanje unutar inače za svakog od ovih subjekata zakonima i pravilnicima jasno određenih obaveza.

Kako je ovaj Zakon donet 2020.g., a već je pokazao očigledne manjkavosti, šta više i da poseduje protivustavne elemente kao i elemente u direktnoj suprotnosti sa oficijelno potvrđenim legislativnim elementima međunarodnog prava, to je jasno da sve što smo u tekstu izložili upućuje na potrebu da se na njegovoj rekonstrukciji angažuje Ustavni sud Republike Srbije, što je naš peti predlog.

\title{
LITERATURA
}

(1) Akcioni plan za sprovođenje Strategije prevencije i suzbijanja trgovine ljudima, posebno ženama i decom i zaštite žrtava za 2019. i 2020. godinu, Sl. glasnik $R S$, br. 50/2019.

(2) Barrenechea López, G. P. (2017) Gender in Transitional Justice Contexts: Reproductive Rights in the Spanish Case of Stolen Babies (Master Thesis). Faculty of Law, Lund University. Dostupno na https://lup.lub.lu.se/studentpapers/search/publication/8919469, stranici pristupljeno 21.1.2021.

(3) Beachy, P., Deacon, J. (1992) Preventing neonatal kidnapping. Journal of Obstetric, Gynecologic, \& Neonatal Nursing, 21(1), 12-16. https://doi.org/10.1111/j.15526909.1992.tbo1716.x

(4) Burgess, A. W., Lanning, K. V. (Eds.). (1995) An analysis of infant abductions. National Center for Missing \& Exploited Children. New York: National Center for Missing \& Exploited Children.

(5) Carroll, V. (1999) Infant abduction: Lowering the risk. Nursing for Women's Health, 3(6), 25-27. https://doi.org/10.1111/j.1552-6356.1999.tbo1145.x

(6) Convention for the Protection of Human Rights and Fundamental Freedoms, as amended by Protocols No. 11 and 14, Rome, 4. XI 1950, European Treaty Series, No. 5, known as the European Convention on Human Rights (ECHR).

3 Utvrdivi po osnovu: čl. 4., st. 1. t. 1 i 14, te čl 17., st. 1. i čl. 18, st. 1. Zakona o zaštiti podataka o ličnosti, Sl. glasnik Republike Srbije, br. 87/2018.g. 


\author{
Zbornik IKSI, 1/2021 - V. Joldžić \\ „Potreba i mogućnosti pravnog sagledavanja i tretmana nestanka beba”, (str. 103-132)
}

(7) European Commission (2017) Transnational Referral Mechanism Model - TRM. https://ec.europa.eu/anti-trafficking/eu-policy/transnational-referral-mechanismmodel-\%E2\%80\%93-trm_en, stranici pristupljeno 20.11.2020.

(8) EU Information Centre in Belgrade (2014) Negotiation Chapters. 35 Steps towards the European Union.

(9) General Assembly Resolution 319 (IV): Provisions for the functioning of the High Commissioner's Office for Refugees, 16 August 1950.

(10) Gilli, G.A. (1974) Kako se istražuje - vodič u društvenim istraživanjima. Zagreb: Školska knjiga.

(11) Hague Convention on the Civil Aspects of International Child Abduction (Hague Abduction Convention), Hague, 25 October 1980.

(12) International Covenant on Economic, Social and Cultural Rights, UN General Assembly resolution 2200A (XXI), of $16^{\text {th }}$ December 1966.

(13) Izveštaj zaštitnika građana o slučajevima tzv. „nestalih beba“ sa preporukama, Del.br. 12443, 29.7.2010.

(14) Jovanović, J. (2016) Nadzor Komiteta ministara Saveta Evrope nad izvršavanjem presuda Evropskog suda za ljudska prava (magistarska teza). Pravni fakultet Univerziteta u Novom Sadu.

(15) Konvencija Ujedinjenih nacija o pravima deteta, Sl. list SCG - Međunarodni ugovori, br. 9/2003.

(16) Krivični zakonik, Sl. glasnik RS, br. 85/05, 88/05, 107/05, 72/09 i 111/2009.

(17) Odluka o obrazovanju komisije za prikupljanje činjenica o statusu novorođene dece za koju se sumnja da su nestala iz porodilišta u Republici Srbiji, Sl. glasnik RS, br. 98/2020.

(18) Predlog zakona o utvrđivanju činjenica o statusu novorođene dece za koju se sumnja da su nestala iz porodilišta u Republici Srbiji - tekst propisa od 28.10.2016.

(19) Rabun, J. B. (2009) For healthcare professionals: Guidelines on prevention of and response to infant abductions. National Center for Missing \& Exploited Children. Washington: National Criminal Justice Reference Service (NCJRS).

(20) Rešenje ministra unutrašnjih poslova o obrazovanju Posebne radne grupe za sprovođenje i praćenje Strategije prevencije i suzbijanja trgovine ljudima, posebno ženama i decom i zaštite žrtava, broj 1860/18-8, od 29.5.2018. godine.

(21) Strategija prevencije i suzbijanja trgovine ljudima, posebno ženama i decom i zaštite žrtava 2017-2022, Sl. glasnik RS, br. 77/2017.

(22) UNICEF (1989) The United Nations Convention on the Rights of the Child (UNCRC). Dostupno na

https://treaties.un.org/Pages/ViewDetails.aspx?src=IND\&mtdsg_no=IV$11 \&$ chapter $=4$, stranici pristupljeno 20.8.2019.

(23) United Nations. (1945) Charter of the United Nations.

(24) United Nations. (1948) The Universal Declaration of Human Rights (United Nations General Assembly Resolution 217 A, Paris on 10 December 1948).

(25) Uredba o Kancelariji za ljudska i manjinska prava, Sl. glasnik RS, br. 75/2012.

(26) Ustav Republike Srbije, Sl. glasnik RS, br. 98/2006.

(27) Šešić, B. (1974) Osnovi metodologije društvenih nauka. Beograd: Naučna knjiga.

(28) Zakon o ministarstvima, Sl. glasnik RS, br. 128/2020.

(29) Zakon o obligacionim odnosima, Sl. list SFRJ, br. 29/78, 39/85, 45/89, 57/89 i $31 / 1993$.

(30) Zakon o postupku utvrđivanja činjenica o statusu novorođene dece za koju se sumnja da su nestala u porodilištima u Republici Srbiji, Sl. glasnik RS, br. 18/2020.

(31) Zakon o potvrđivanju Konvencije Saveta Evrope o borbi protiv trgovine ljudima, $S l$. glasnik RS - Međunarodni ugovori, br. 19/2009. 


\author{
Zbornik IKSI, 1/2O21 - V. Joldžić \\ „Potreba i mogućnosti pravnog sagledavanja i tretmana nestanka beba”, (str. 103-132)
}

(32) Zakon o potvrđivanju Fakultativnog protokola o prodaji dece, dečijoj prostituciji i dečijoj pornografiji, uz Konvenciju o pravima deteta, Sl. list SRJ - Međunarodni ugovori, br. 7/2002.

(33) Zakon o ratifikaciji Evropske konvencije za zaštitu ljudskih prava i osnovnih sloboda, izmenjene u skladu sa Protokolom broj 11, Protokola uz Konvenciju za zaštitu ljudskih prava i osnovnih sloboda, Protokola broj 4 uz Konvenciju za zaštitu ljudskih prava i osnovnih sloboda kojim se obezbeđuju izvesna prava i slobode koji nisu uključeni u konvenciju i prvi protokol uz nju, Protokola broj 6 uz Konvenciju za zaštitu ljudskih prava i osnovnih sloboda o ukidanju smrtne kazne, Protokola broj 7 uz Konvenciju za zaštitu ljudskih prava i osnovnih sloboda, Protokola broj 12 uz Konvenciju za zaštitu ljudskih prava i osnovnih sloboda i Protokola broj 13 uz Konvenciju za zaštitu ljudskih prava i osnovnih sloboda o ukidanju smrtne kazne u svim okolnostima, Sl. list SCG - Međunarodni ugovori, br. 9/2003, 5/2005 i 7/2005 - ispr. i Sl. glasnik RS - Međunarodni ugovori, br. 12/2010 i 10/2015.

(34) Zakon o ratifikaciji Konvencije o građanskopravnim aspektima međunarodne otmice dece, Sl. list SFRJ - Međunarodni ugovori, br. 7/1991.

(35) Zakon o ratifikaciji Međunarodnog pakta o ekonomskim, socijalnim i kulturnim pravima, Sl. list SFRJ, br. 7/1971.

(36) Zakon o slobodnom pristupu informacijama od javnog značaja, Sl. glasnik $R S$, br. 120/2004, 54/2007, 104/2009 i 36/2010.

(37) Zakon o utvrđivanju činjenica o statusu novorođene dece za koju se sumnja da su nestala iz porodilišta u Republici Srbiji, Sl. glasnik RS, br. 18/2020.

(38) Zakon o zaključivanju i izvršavanju međunarodnih ugovora, Sl. listu SFRJ, br. $55 / 78,2 / 89$ i 47/1989.

(39) Zakon o zaključivanju i izvršavanju međunarodnih ugovora, Sl. glasnik RS, broj $32 / 2013$.

(40) Zakon o zaštiti podataka o ličnosti, Sl. glasnik RS, br. 87/2018.

\title{
Internet izvori
}

(41) Collins, T.R. (2006) Code Pink. The Hospitalist. Dostupno na https://www.thehospitalist.org/hospitalist/article/123116/code-pink, stranici pristupljeno 10.10.2020.

(42) Committee of Ministers, Secretariat Genral, DH-DD (2016)254, Meeting: 1250 (810 March 2016) (DH). Dostupno na

https://rm.coe.int/CoERMPublicCommonSearchServices/DisplayDCTMContent?d ocumentId=09000016805acecc, stranici pristupljeno 5.10.2020.

(43) Confidential Report on the Conference on Migration Held at Brussels, Belgium From November 26 Through December 5, 1951 and the Session of the Provisional Intergovernmental Committee for the Movement of Migrants From Europe Held at Brussels From December 6 Through December 8, 1951. Washington, January 17, 1952. Memorandum by George L. Warren of the Refugees and Displaced Persons Staff of the Bureau of United Nations Affairs. Dostupno na https://history.state.gov/historicaldocuments/frus1951vo4p1/d83, stranici pristupljeno 10.10.2020.

(44) European Court for Human Rights, Second Section, Case of Zorica Jovanović v. Serbia (Application No. 21794/o8), Judgment, Strasbourg, 26 March 2013, Final 09/09/2013. Dostupno na https://hudoc.echr.coe.int/fre\#\{\%22itemid\%22:[\%22001-118276\%22]\}, stranici pristupljeno 10.10.2020. 


\author{
Zbornik IKSI, 1/2O21 - V. Joldžić \\ „Potreba i mogućnosti pravnog sagledavanja i tretmana nestanka beba”, (str. 103-132)
}

(45) Glavonjić, Z. (2020) Nestale bebe u Srbiji: Činjenice i njihove posledice. Radio Slobodna Evropa. https://www.slobodnaevropa.org/a/nestale-bebe-u-srbiji\%C4\%8Dinjenice-i-njihove-posledice/30466633.html, stranici pristupljeno 22.1.2020.

(46) International Covenant on Civil and Political Rights (ICCPR), United Nations General Assembly Resolution No 2200A (XXI), 19 December 1966. Dostupno na https://treaties.un.org/doc/publication/unts/volume\%20999/volume-999-i14668-english.pdf, stranici pristupljeno 20.6.2018.

(47) Martinović, I. (2018) Decenija i po portage za nestalim bebama. Radio Slobodna Evropa. https://www.slobodnaevropa.org/a/nestale-bebe-decenija-i-po-borbasrbija/29236151.html, stranici pristupljeno 20.1.2020.

(48) Milutinović, A. (2019) NOVI PODACI U AFERI VEKA - "NESTALE BEBE" Slučaj mladića iz Srbije koji je hteo da sazna ko su mu pravi roditelji dobila je ŠOKANTNI NASTAVAK. Dostupno na https://www.blic.rs/vesti/drustvo/novi-podaci-u-aferiveka-nestale-bebe-slucaj-mladica-iz-srbije-koji-je-hteo-da-sazna/npohwfy, stranici pristupljeno 20.1.2021.

(49) Novosti. (2020) 684 sumnji na nestanak beba u porodilištima. Dostupno na https://www.blic.rs/vesti/drustvo/684-sumnji-na-nestanak-beba-u-porodilistimaovoliko-prijava-dobili-su-sudovi-sirom/3cmfn6, stranici pristupljeno 20.1.2021.

(50) Odluka o obrazovanju Saveta za borbu protiv trgovine ljudima, Sl. glasnik RS, br. $92 / 2017$.

(51) Office of the United Nations High Commissioner for Human Rights (Office of the High Commissioner for Human Rights (OHCHR) or the United Nations Human Rights Office), UN General Assembly Resolution 48/141, December 1993. Dostupno na http://www.un-documents.net/a48r141.htm, stranici pristupljeno 15.1.2021.

(52) Optional Protocol to the Convention on the Rights of the Child on the sale of children, child prostitution and child pornography, UN General Assembly resolution A/RES/54/263 of 25 May 200o. Dostupno na https://www.ohchr.org/en/professionalinterest/pages/opsccrc.aspx, stranici pristupljeno 20.12.2020.

(53) Rakić Vodinelić, V., Ćurčić, D (2014) Zakon o istraživanju položaja nestale novorođenčadi. Alternativa: Zakon o izvršenju obaveza Republike Srbije iz presude Evropskog suda za ljudska prava u predmetu Zorica Jovanović protiv Srbije (br. 21794/o8). Dostupno na https://pescanik.net/wpcontent/PDF/zakononestalimbebama.pdf, stranici pristupljeno 9.1.2021.

(54) Sundberg, F. (2019) U Strazburu petnaest tužbi za nestale bebe. Radio Slobodna Evropa. https://www.slobodnaevropa.org/a/intervju-fredriksundberg/30316493.html, stranici pristupljeno 20.1.2021. 


\section{THE NEED AND POSSIBILITIES OF LEGAL CONSIDERATION AND TREATMENT OF THE DISAPPEARANCE OF BABIES}

The subject of the paper, obvious from the title itself, arose from our interest in whether there is an adequate socio-legal reaction to the disappearance of babies from the maternity hospital, especially at domestic terrain. It is a phenomenon that is claimed to have been present for decades not only in Serbia but in practically all countries. In Serbia, for many years, parents who claim that their baby was stolen from the maternity hospital were asked to pass a law that would treat it appropriately. The same requires a decision of the European Court of Human Rights in the case of Zorica Jovanovic $v$. Serbia. Therefore, it is not surprising that it has been worked on in Serbia since 2014. When it was passed, it immediately caused controversy, and so did our suspicions. Hence our desire to analyze it, and in this way to point out the possible ways, means and elements necessary for the correction of its shortcomings, if we notice them.

KEY WORDS: international law / Constitution / laws / institutions / protection of rights 